\title{
LOS SANTOS DOMINICOS Y LA PROPAGANDA INQUISITORIAL EN EL CONVENTO DE SANTO TOMÁS DE ÁVILA ${ }^{1}$
}

\author{
DOMINICAN SAINTS AND INQUISITORIAL PROPAGANDA \\ IN SAINT THOMAS OF AVILA CONVENT
}

SONIA CABALLERO ESCAMILLA
Universidad de Salamanca

Resumen: En este artículo analizamos las pinturas de Santo Domingo de Guzmán, Santo Tomás de Aquino y San Pedro de Verona del Convento de Santo Tomás de Ávila y su iconografía en relación con el contexto histórico original. La interpretación de las imágenes revela algunos aspectos de la persona que, hipotéticamente, encargó las pinturas y que diseñó el mensaje, el inquisidor Torquemada, así como sus objetivos.

Palabras clave: Orden dominica; Iconografía; Propaganda; Herejía.
Abstract: In this study, we analyze the paintings of the Saint Domingo of Guzmán, Saint Thomas of Aquino and Saint Peter of Verona of the monastery of Saint Thomas in Ávila and their iconography in relation to the original historical context. The interpretation of the images shows some aspects about the person who commissions the paintings and who designed the message, the inquisitor Torquemada, as well as his aim.

Keywords: Dominican Order; Iconography; Propaganda; Heresy.

\section{SUMARIO}

1. Los fundadores.- 2. El contexto histórico.- 3. ¿Quién fue el mentor iconográfico? Algunas hipótesis.- 4. Las imágenes de los santos dominicos en sus retablos: 4.1 Santo Tomás de Aquino. 4.2. Santo Domingo de Guzmán. 4.3. San Pedro de Verona.

\section{LOS FUNDADORES}

El Convento de Santo Tomás de Ávila es uno de los edificios más emblemáticos del tardogótico hispano y uno de los más sobresalientes por su

${ }^{1}$ Becaria de investigación de la Fundación del Patrimonio Histórico de Castilla y León. Teniendo en cuenta las limitaciones de espacio, nuestro objetivo no es el análisis completo de los tres retablos que presidieron ẹl Altar Mayor y el crucero del Convento de Santo Tomás de Avila, sino poner de manifiesto las intencionalidades subyacentes en la elección de los temas. 
significación no sólo en el plano artístico sino también desde el punto de vista histórico porque, aunque no estuvo planteado en sus inicios, lo cierto es que acabó siendo sede del tribunal de la Inquisición con fray Tomás de Torquemada a la cabeza, un hecho que influyó muy directamente en la concepción de las obras artísticas que ocuparon diversas partes del edificio [Fig. 1].

Como queda suficientemente probado en la documentación, Fernán Núñez de Arnalte, tesorero de los Reyes Católicos, tuvo la iniciativa de fundar un convento dedicado a Santo Tomás de Aquino en la ciudad de Ávila. No obstante, no pudo ver cumplidos sus deseos en vida al sobrevenirle la muerte de forma inesperada. Pero ¿cuáles fueron sus intenciones y hasta qué punto se cumplieron?

Como indicó el propio tesorero en el momento de redactar su testamento, debido a la gravedad de su enfermedad, no podía "fazer, nin hordenar nin espremir nin declarar nin otorgar mi testamento e postrera voluntad"2. Por este motivo, delegó todo su poder en su esposa María Dávila y en fray Tomás de Torquemada, prior del Convento de Santa Cruz de Segovia en aquel momento. La relación del tesorero con este último debió de ser bastante estrecha, tal y como él mismo expresa en su testamento, y, como consecuencia de ello, tanto su esposa como su gran amigo eran los mejores conocedores de sus voluntades: “...cada uno dellos, saben mi entinçión e voluntad de todo lo susodicho, segund que con ellos yo fablé"3.

Una de las cláusulas del testamento del tesorero hacía referencia a su devoción por la orden de Santo Domingo y la figura de Santo Tomás de Aquino y a su deseo de construir una iglesia y convento, donde habitaran los frailes, dedicado al santo de Aquino en la ciudad de Ávila. Para ello, y en nombre del Tesorero, María Dávila y fray Tomás de Torquemada ordenaron que se otorgara la cantidad de un cuento y quinientos mil maravedís para comenzar la obra y, lo que es más importante, ordenaron "que se pongan las armas del dicho tesorero porque su memoria sea como dicho es conservada e otros tomen cobdicia de faser otras obras piadosas semejantes a ésta" ${ }^{4}$. No sabemos si este último punto se llegó a cumplir porque, al menos en el edificio actual, no aparece ningún escudo de Don Fernando, el primitivo fundador. Tal vez nunca se pusieron o bien fueron eliminados en el transcurso posterior de las obras cuando los Reyes Católicos apoyaron, tanto económica como ideológicamente, la construcción, siendo sustituidos por los emblemas regios.

\footnotetext{
${ }^{2}$ Archivo del Convento de las Gordillas en Ávila (en adelante ACG). Testamento de don Fernando Núñez de Arnalte, tesorero y secretario de los Reyes Católicos, marido de doña María de Avila. Cajón 9, doc. 2. Transcrito en Tomás SOBRINO CHOMÓN, Un linaje abulense en el S. XV: Doña María Dávila (Documentación medieval del monasterio de las Gordillas), vol. II, Avila, 1998, p. 115.

${ }^{3}$ Ibídem, p. 116.

${ }^{4}$ ACG, Cláusula del testamento de Fernán Núñez en que haze ziertas mandas para la rredificazión del Convento de Santo Thomás de Avila, Cajón $6, n^{\circ} 2$, (sin numeración en páginas).
} 
A pesar de que tanto María Dávila como fray Tomás de Torquemada se encargaron de llevar a cabo las voluntades del tesorero, María Dávila acabó delegando todo el poder en el fraile que se convertiría así en el más directo responsable de la construcción:

...porque más ayna e mejor el dicho monasterio e capilla e yglesia se faga yo la dicha dona María de Ávila rogué e ruego al dicho señor prior fray Tomás de Torquemada que le plega de tomar e rescebir el cargo e principio de faser el dicho monasterio e capilla e yglesia e yo el dicho prior digo que me plase e so contento de tomar e rescebir el dicho cargo de faser e hedificar el dicho monasterio como dicho es dándome para ello licencia e facultad de mandamiento espreso del nuestro muy santo padre o del maestro de la orden o del su vicario de la dicha observancia.

En definitiva, y tal y como se desprende de estas palabras, la idea de edificar el convento de Santo Tomás partió de Fernán Núñez de Arnalte; por deseo expreso de éste, los encargados de materializar su voluntad fueron María Dávila y el prior de Santa Cruz de Segovia, pero, por petición expresa de $\mathrm{D}^{\mathrm{a}}$ María, quien en primera instancia se puso al frente de la empresa fue fray Tomás de Torquemada 5 . No obstante, hemos de introducir un nuevo nombre, fray Alonso de Valisa. Al poco tiempo del comienzo de las obras, en concreto el 15 de noviembre de 1482, sin especificar los motivos, fray Tomás de Torquemada nombra como sucesor al frente de la edificación del convento al entonces subprior del Convento de Santa Cruz de Segovia, fray Alfonso de Valisa:

...por ende yo el dicho prior fray Tomás de Torquemada....usando del dicho poder a mí dado e otorgado...nombro e sostituyo como mejor puedo e devo en mi logar e en mi nombre... al discreto religioso fray Alfonso de Valisa soprior del dicho monasterio de Santa Crus de Segovia que está presente e le do e otorgo todo poder conplido...para que tome e tenga el cargo de faser edificar el dicho monasterio en los dichos aravales dela dicha cibdad de Ávila donde ya está começados e para que pueda demandar e rescebir, aver e recabadar e cobrar de la dicha señora doña María de Ávila...a dar el dicho un cuento e quinientas mill maravedís sobre lo que ya dello está dado para la dicha edificación e las dichas seiscientas fanegas de pan terciado de renta e el previllejo de los dichos cuarenta e nueve mill e setencientos maravedís de juro para el mantenimiento e sustentación de los frailes... 6 .

${ }^{5}$ Los distintos eștudiosos han planteado la problemática existente en torno a los fundadores del convento proponiendo diversas teorías. Por poner algún ejemplo, Fernández Casanova publicó a principios del S. XX un artículo en el que consideraba como fundadores de la iglesia de Santo Tomás a los Reyes Católicos, Iglesia de Santo Tomás de Avila. Fundación de los Reyes Católicos, "Boletín de la Sociedad Española de Excursiones", XII, (1904), pp. 169-175. Una publicación más reciente estudia los retablos como un ençargo real. Vid. Emilio RoDRÍGUEZ ALMEIDA, El testamento espiritual de Pedro Berruguete, Avila, 2003, p. 28 . En cambio Post hacía responsable de estos encargos artísticos al inquisidor. Ch. R. POST, A history of Spanish Painting, Cambridge, Massachusets, 1947, p. 36.

${ }^{6}$ ACG, Claúsula del testamento de Fernán Núñez en que haze ziertas mandas para la rredificazión del Convento de Santo Thomás de Avila, Cajón $6, \mathrm{n}^{\mathrm{o}} 2$ (sin numeración en páginas). 
Lo cierto es que las obras ya habían comenzado por esas fechas y fray Alfonso de Valisa sustituyó a fray Tomás de Torquemada en el cargo, aunque las directrices ya estaban dadas.

El Convento de Santo Tomás contó también con el respaldo de la pareja regia formada por D. Fernando e Isabel, los Reyes Católicos, quienes colaboraron económicamente en su construcción. La presencia de sus emblemas en diversas partes del edificio demuestra su participación. De hecho, el propio Fernando el Católico considera el convento de Santo Tomás como una fundación real en su testamento de $1510^{7}$. Así es presentado también por los viajeros contemporáneos, como es el caso de Jerónimo Münzer quien en su "Viaje a España" dice los siguiente: "El rey, juntamente con la reina...fundan y dotan numerosos monasterios. Actualmente están edificando en la ciudad de Ávila un monasterio superior a los demás, llamado de Santa Cruz..."

Ahora bien, la representación de los emblemas reales -el yugo y las flechas- así como los ramos de granado que aparecen por doquier en distintos ámbitos del edificio, no son una razón suficiente que acrediten la tesis de un patronazgo regio, excluyendo otras hipótesis. La utilización de los símbolos regios en una obra que no ha sido alentada únicamente por los Reyes fue una práctica habitual a finales de la Edad Media, como se puede observar en un edificio muy vinculado al que nos ocupa, el Convento de Santa Cruz de Segovia y la Santa Cueva, donde Santo Domingo gozaba de experiencias visionarias y se autoflagelaba. A menudo, mediante la presencia del escudo o emblema real, se pretendía mostrar una cercanía a los Reyes así como su respaldo en determinadas cuestiones ideológicas ${ }^{9}$. En el caso que hemos citado, el programa iconográfico desplegado en la portada de la Santa Cueva, hace referencia al triunfo de la Iglesia, con los dominicos a su cabeza, sobre las herejías ${ }^{10}$. La imágenes reales vendrían a ratificar el apoyo otorgado por la monarquía a la causa antiherética protagonizada por la Orden de Santo Domingo. Así se deduce del propio epígrafe de la portada: "Pues Dios con los Santos, a vos Reyes, iguala en el tener mandados favoresçer su Fe católica los

${ }^{7}$ Pilar Silva Maroto, ficha del retablo de San Pedro Mártir conservado en el Museo del Prado y procedente del convento de Santo Tomás de Ávila; en el Catálogo de la exposición Pedro Berruguete. El primer pintor renacentista de la Corona de Castilla, Junta de Castilla y León, 2003, p. 188.

${ }^{8} \mathrm{La}$ advocación de Santa Cruz es errónea y debe de tratarse de una confusión del viajero. El texto está citado por Fernando CHECA CREMADES, Isabel de Castilla: los lenguajes artísticos del poder "Catálogo de la exposición" Isabel la Católica. La magnificencia de un reinado, Valladolid, 2004, p. 23.

${ }^{9}$ Un ejemplo de este tipo es la "Virgen de la Misericordia" del Monasterio de las Huelgas. Joaquín YARZA LUACES, Imágenes reales hispanas en el fin de la Edad Media "23 Semana de Estudios Medievales de Estella" 22-26 de julio, 1996; Poderes públicos en la España medieval: principados, reinos y coronas, Pamplona, 1997, p. 465.

${ }^{10}$ La figura de Santo Domingo se sitúa en el centro. Sostiene una cruz cuyos brazos están apoyados en los de Fernando e Tsabel identificados por sus emblemas. Hemos analizado esta iconografía en Sonia CABALLERO ESCAMILLA, Fray Tomás de Torquemada, iconógrafo y promotor de las artes, "Archivo Español de Arte". En prensa. 
dos"11. Es posible que su aparición se deba a una exaltación de la Inquisición a través de sus imágenes más que a su intervención directa en la obra.

Por tanto, en el Convento de Santo Tomás de Ávila no podemos aceptar la tesis de que fueron los Reyes Católicos quienes dirigieron las obras que allí se llevaron a cabo, basándonos únicamente en la presencia de sus emblemas en la fachada. Más aún si tenemos en cuenta que fue Torquemada quien ordenó disponer las armas de los monarcas en las partes principales del convento: “...mandó grabar las armas de los Católicos Reyes en las partes principales del convento: escaleras, claustros e iglesia y sillería del coro..."12. $\mathrm{Si}$ atendemos a las palabras expresadas por el papa Alejandro VI el 12 de noviembre de 1496, los Reyes colaboraron en el plano económico, pero el auténtico responsable de la fundación fue fray Tomás de Torquemada:

Erigiste desde los primeros cimientos en la ciudad de Ávila, con la generosidad de dichos reyes y con algunas penitencias impuestas por arbitrio de los inquisidores a los que se reintegraban a la fe, el insigne monasterio de tu Orden de Predicadores bajo la invocación del santo doctor Tomás de Aquino ${ }^{13}$.

\section{El CONTEXTO HISTÓRICO}

Un edificio como el que nos ocupa no se puede entender si no es en relación con el contexto histórico en el que surge. Es cierto que nació como una fundación que respondía a la devoción del tesorero de los Reyes Católicos hacia los dominicos en general y Santo Tomás de Aquino en particular. Sin embargo, a diferencia del comportamiento habitual de la época, en la que los fundadores de edificios religiosos tenían la intención de convertirlos en su última morada, y a tenor de lo expuesto en su testamento, la voluntad de Fernán Núñez de Arnalte fue enterrarse en la iglesia de San Miguel de Ocaña donde estaban sepultados sus padres, expresando a $\mathrm{D}^{\mathrm{a}}$ María y a fray Tomás los detalles de sus exequias ${ }^{14}$. Hoy podemos ver los restos de su sepulcro en una de las capillas de la iglesia de Santo Tomás: el traslado de su cuerpo se efectuó más tarde a instancias de $\mathrm{D}^{\mathrm{a}}$ María ${ }^{15}$.

\footnotetext{
${ }^{11}$ Para el caso del convento de la Santa Cruz de Segovia y el contexto inquisitorial, consúltese el artículo Eduardo CARRERO SANTAMARÍA, Patrocinio regio e Inquisición. El programa iconográfico de la cueva de Santo Domingo en Santa Cruz la Real de Segovia. "Actas del Congreso Internacional" Gil de Siloé y la escultura de su tiempo, (Burgos, 13-16 de octubre de 1999), 2001, pp. 447-462.

${ }^{12}$ Archivo del convento de Santo Tomás de Ávila (ACSTA), documento fechado en septiembre de 1688. Cajón $n^{\circ} 1, n^{\circ} 4$. Vid. Libro Becerro de 1776.

${ }^{13} \mathrm{G}$. MARTÍnEZ DÍAZ, Bulario de la Inquisición española hasta la muerte de Fernando el Católico, Madrid, 1997, pp. 288-289.

${ }^{14}$ ACG, Testamento de don Fernando Núñez de Arnalte, tesorero y secretario de los Reyes Católicos, marido de doña María de Avila, cajón 9, doc. 2.'Transcrito en Tomás SOBRINO, Un linaje abulense, ob.cit., p. 115.

${ }^{15}$ ACG, Para trasladar el cuerpo de Fernán Núñez a Santo Thomás de Ávila, cajón 12, no 11.
} 
Por tanto, a la muerte de D. Fernán Núñez de Arnalte se da comienzo a la obra del insigne convento dominico. El lugar elegido fue el de unas casas, huertas y prado que $\mathrm{D}^{\mathrm{a}}$ María y fray Tomás habían comprado al canónigo Fernán González en los arrabales de la ciudad de Ávila con el dinero legado por el tesorero. Era un solar que "estava apartado de iglesias perrochiales e donde non se fasía agrabio a ninguna persona e avía anchura e logar donde el tal monasterio se fisiese e se pudiese estender la obra e edificios del dicho monasterio e casa..."16.

De este modo, se obtienen los permisos oportunos porque no había en la ciudad de Ávila otro edificio de la misma orden y se considera que "el dho monasterio era necesario para la edificación de los vesinos y moradores desta cibdad e de sus conciencias así en la abdicio e celebración de los oficios divinos como en las confisiones e predicaciones..."17.

A finales del S. XV muchas ciudades hispánicas habían sufrido episodios de intolerancia y violencia entre judíos y cristianos reflejados en devastaciones de sinagogas y juderías.

La actitud de rechazo hacia los judíos se había provocado desde diferentes ámbitos, entre ellos, el eclesiástico, como prueban las noticias conocidas acerca de algunos predicadores, como el conocido arcediano de Écija o el valenciano fray Vicente Ferrer. De ese modo, surge toda una serie de tópicos negativos aplicados a la figura del judío, fomentando el odio hacia todo lo que suponía la ley mosaica ${ }^{18}$. Pero en el S. XV al problema judío se sumó el converso. Después de la oleada de conversiones masivas, las sospechas recayeron sobre los conversos, a los que se acusaba de practicar su antigua religión de forma oculta. Así, se creó un clima de desasosiego no sólo entre los falsos conversos sino también entre los verdaderos, que tenían que soportar el dedo acusador de sus vecinos ${ }^{19}$.

${ }^{16}$ ACG, Claúsula del testamento de Fernán Núñez en que haze ziertas mandas para la rredificazión del Convento de Santo Thomás de Avila, Cajón 6, no 2 (sin numeración en páginas).

${ }^{17}$ ACG, Claúsula del testamento de Fernán Núñez en que haze ziertas mandas para la rredificazión del Convento de Santo Thomás de Avila, Cajón $6, \mathrm{n}^{\mathrm{o}} 2$ (sin numeración en páginas).

${ }^{18}$ José M Monsalvo AnTón, Mentalidad antijudía en la Castilla medieval. Cultura clerical y cultura popular en la gestación y difusión de un ideario medieval, en Carlos BARRÓN (ed.), "Actas do Congreso Internacional" Xudeus e Conversos na Historia. Mentalidades e Cultura, I, (Rivadavia, 14-17 de octubre de 1991), Santiago de Compostela, 1994, pp. 21-85.

${ }^{19} \mathrm{La}$ lista de estudios sobre el tema es interminable. Citaré en este caso los siguientes, remitiendo al lector a la bibliografía citada en algunos de estos trabajos: Emiliọ MITRE EERNÁNDEZ, Judaísmo y Cristianismo. Raíces de un gran conflicto histórico, Madrid, 1980; Ángel AlCALÁ (ed.), Judios. Sefarditas. Conversos la expulsion de 1492 y sus consecuencias, "Actas del Congreso Internacional" (Nueva York, 1992), Valladolid, 1995. M a Pilar RÁBADE OBRADÓ, Una élite de poder en la corte de los Reyes Católicos: los judeoconversos, Madrid, 1993; Idem, Unir y separar: algunos efectos socio-religiosos de la acción inquisitorial durante el reinado de Isabel I, "Arbor" CLXXVIII, 701, Mayo, 2004, pp. 67-86. Miri RUBIN, Gentile Tale. The Narrative Assault on Late Medieval Jews, Yale, 1999; David NIREMBERG, Comunidades de violencia. La persecución de las minorías en la Edad Media, Barcelona, 2001; Julio VALDEÓN BARUQUE, Judios y conversos en la Castilla medieval, Valladolid: Ambito, 2004; IDEM, El chivo expiatorio: judios, revueltas y vida cotidiana en la Edad Media, Valladolid: Ámbito ( $2^{\text {a }}$ edición), 2004. 
Pero veamos qué ocurría en Ávila a finales del S. XV. Los distintos testimonios documentales presentan un ambiente de cierta tranquilidad con respecto a otras zonas. Por citar un ejemplo, el Sínodo de Alonso de Fonseca de 1481 demuestra que judíos y musulmanes participaban de forma pacífica en las procesiones:

Una abusión avemos visto fazer en esta ciudad de Ávila, la qual en ningún lugar de cristianos vimos, que los judíos y moros son compelidos a andar en procesión y facer danzas y otras alegrías el día del Cuerpo de Nuestro Señor, y otras procesiones generales de religiosa y cristiana alegría...y non sabemos por qué razón o con qué ceguedad se viene tolerando estos abusos $^{20}$.

No obstante, el rechazo radical que se vio en otras zonas desde el S. XIV tendría entrada en la ciudad mucho después. Los episodios violentos documentados tuvieron lugar a raíz del proceso más conocido de la historia de la Inquisición, el del "Santo Niño de La Guardia"12. Anteriormente solamente están registrados robos o quejas en el plano económico o judicial.

El auto de fe celebrado en Ávila en 1491, en el que se castigó a los supuestos responsables del crimen, constituyó el atenuante de la expulsión de $1492^{22}$. Y quizás fue el móvil que impulsó la elección de Ávila como escenario de este acto. Un golpe de este tipo podía modificar estados de opinión, exaltando los ánimos de la población en la dirección deseada ${ }^{23}$, como así fue. A raíz del auto de fe citado, "se agrava la hostilidad del vecindario contra los judíos: los apedrean por las calles y persiguen y maltratan a sus familiares y criados..." ${ }^{24}$, lo que les lleva a solicitar una carta de seguridad a los monarcas. Este falso crimen contribuyó a transformar la opinión pública y a ejercer una presión sobre los Reyes.

\section{3. ¿QUIÉN FUE EL MENTOR ICONOGRÁFICO? ALGUNAS HIPÓTESIS}

El hecho de no contar con un documento escrito que acredite la identidad del mentor o mentores iconográficos que dirigieron las distintas

\footnotetext{
${ }^{20}$ Antonio GarCÍA Y GarCía, Synodicon Hispanum IV. Ávila y Segovia, Madrid, MCMXCIII, p. 205.

${ }^{21}$ Sobre este aspecto véase, Sonia CABALlero, El caso del Santo Niño de La Guardia y sus efectos sobre la convivencia entre culturas en la ciudad de Avila, "Encuentros Internacionales del Medievo" La convivencia en las ciudades medievales (Nájera 24-27 de julio de 2007), Logroño, 2008, pp. 157-172.

${ }^{22}$ Como señaló Pilar Huerga, La Guardia pertenecía a la jurisdicción de Toledo. El inquisidor General Fray Tomás de Torquemada. Una inquisición nueva, en J. CONTRERAS, Nuevas aproximaciones. Inquisición española, Madrid, 1987, pp. 7-51.

${ }^{23} \mathrm{La}$ acusación a los judíos de llevar a cabo crímenes rituales no es nueva. Se trata de un tópico más, utilizado para acentuar un sentimiento antijudío. Hemos hecho comentarios al respecto en S. CABALLERO, El caso del Santo Niño, ob.cit.

${ }^{24}$ Pilar León Tello, Judíos de Ávila, Ávila, 1963, p. 27.
} 
empresas artísticas llevadas a cabo en el Convento, no es un óbice para proponer algunas hipótesis, atendiendo al carácter de las obras, su significado $\mathrm{y}$, por tanto, su finalidad de acuerdo con el contexto histórico en el que surgieron. Se trata, en definitiva, de devolver la voz a la iconografía.

En este sentido, sabemos que Fernán Núñez de Arnalte fue el primer impulsor de la fundación de un convento dedicado a Santo Tomás de Aquino en Ávila pero, tal y como él mismo dejó expresado en su testamento, fue su mujer María Dávila y el entonces prior de Santa Cruz de Segovia, fray Tomás de Torquemada, quienes materializaron su voluntad después de su temprana muerte ${ }^{25}$. La relación de ambos con los Reyes Católicos -recordemos que Fernán Núñez fue tesorero real, María Dávila, dama del entorno de la Reina y Torquemada confesor real-, les procuró una protección real desde los comienzos, un apoyo que no sólo fue moral sino que se tradujo además en un respaldo económico. Sin embargo, teniendo en cuenta el protagonismo que llegaría a tener en el Convento tras su nombramiento como Inquisidor General $\mathrm{y}$, asimismo, atendiendo a la función del edificio como sede del Tribunal, estamos en disposición de pensar, aunque moviéndonos en el terreno de las hipótesis, en el fraile dominico como iconógrafo ${ }^{26}$. No sería nada extraño teniendo en cuenta su intervención en otra fundación dominica cercana en la que también tuvo un cargo de responsabilidad y en la que Eduardo Carrero ha señalado su probable actuación como mentor iconográfico, el Convento de Santa Cruz de Segovia.

No se conocen muchos datos sobre fray Tomás. Sabemos que nació en Valladolid, comenzando su carrera en el convento de San Pablo de Valladolid donde su tío Juan de Torquemada ocupaba el cargo de prior $^{27}$. Los textos le presentan como un hombre inteligente, culto, severo y austero ${ }^{28}$. Fue hombre de confianza de la reina, lo que le permitió seguir muy de cerca todos los problemas que aquejaban a la monarquía.

\footnotetext{
${ }^{25}$ ACG, Testamento de Fernán Núñez de Arnalte Cajón 9, no 2 Año 1479. 30 M. Transcrito en T. SOBRINO, Un linaje abulense, vol. II, ob.cit., p. 115, n ${ }^{\circ} 176$.

${ }^{26}$ Ya Post indicó la posibilidad de que Torquemada fuera el mentor de los retablos abulenses. Posteriormente, Joaquín Yarza se refirió concretamente al Auto de Fe de Pedro Berruguete señalando a Torquemada como responsable del programa. Por su parte, Eduardo Carrero calificó al dominico como iconógrafo tanto de los retablos de Berruguete en Santo Tomás de Avila como de la "decoración" del conjunto monástico de Santa Cruz de Segovia Vid. Ch. R. POST, A History, ob.cit., p. 36; J. YARZA, Los Reyes Católicos. Paisaje artístico de una monarquía, Madrid, 1993, p. 38; E. CARRERO, Patrocinio regio e Inquisición..(1999), 2001, ob cit.; J. YARZA, Una imagen dirigida: los retablos de Santo Domingo de Guzmán y San Pedro de Mártir de Pedro Berruguete en Historias Inmortales, Barcelona, 2002, pp. 25-54; E. CARRERO, Un panegírico de la predicación. La Exaltación de la Cruz y la iconografía de los Dominicos en Segovia, "Actas del Simposio Internacional" Pedro Berruguete y su entorno (Palencia 24, $25 \mathrm{y}$ 26 de abril de 2004), Palencia, 2004, pp. 361-370.

${ }^{27}$ No obstante existe una noticia que le presenta como "hijo del convento de Piedrahíta". Luis GETINO, O.P. Dominicos españoles confesores de reyes "Ciencia. Tomista", noviembrediciembre, (1916). Santo Domingo el Real, Madrid, 1917. Bibliọteca Nacional de Madrid (BNM). Sala General. Sign. VC/650/25. Parece ser que tras su estancia en Valladolid estuvo destinado en el convento đe Santo Domingo de Piedrahita donde enseñó teología. A. LARIOS RAMOS, Torquemada y la inquisición moderna, "Catálogo de la exposición" Los Inquisidores, Vitoria, 1993, p. 64.

${ }^{28}$ Descripción de Walsh. En J. L. PAJARES, Torquemada, "Redescubrir Ávila. Artículos, fotografías y grabados antiguos", Ǎvila, 1998, pp. 101-112.
} 
Desde un principio le preocupó el problema de la herejía y quiso transmitir este sentimiento a los Reyes ${ }^{29}$. Para ello se valió de un proceso que creó un clima de desasosiego en la población abulense, situando a los judíos y conversos en el punto de mira. El proceso del Santo Niño de La Guardia en que unos judíos y conversos fueron acusados de asesinar a un niño cristiano con el fin de realizar conjuros contra los inquisidores ${ }^{30}$. El resultado fue el mismo que se dio en Zaragoza pocos años antes. La hostilidad del pueblo hacia los inquisidores cambió cuando el Inquisidor General de la Corona de Aragón, Pedro de Arbués, fue asesinado de forma violenta en la Seo de Zaragoza a manos de unos judíos. Este suceso desencadenó el odio hacia la clase judía, a la que consideraban responsable del hecho, y la canonización del inquisidor ${ }^{31}$.

Algunas de las obras que relacionamos con la dirección de fray Tomás de Torquemada se conservan en el lugar para el que fueron concebidas. Sin embargo, otras forman parte de algunas colecciones públicas y privadas después de haber sido víctimas del proceso desamortizador. Para llegar a comprender su significado, debemos analizarlas en función del lugar que ocuparon, la mayoría, en el interior de la iglesia. Los tres retablos más importantes, dedicados a Santo Tomás de Aquino el central y a Santo Domingo de Guzmán y San Pedro Mártir los laterales, se ubicaban en la zona más importante, el altar, rodeados de los sambenitos que colgaban en los muros del crucero 32 : "En la Capilla Mayor de la iglesia de dicho convento de Santo Tomás, que así san benitos sirven de lienzos que ocupan los dos lienzos comenzando desde los colaterales de la Capilla hasta su remate"33. El conjunto, pues, era elocuente sobre el clima que se vivía en aquel momento; los símbolos de los herejes vencidos se mostraban ante los ojos de los fieles junto a los victoriosos adalides del cristianismo. Pero no sólo eso, sino que Torquemada no se limitó a presentar la historia de los tres principales santos de la Orden sino que, en algunos detalles, alteró la historia para encumbrar el Tribunal de la Inquisición y así legitimar la represión.

Confió la empresa a uno de los mejores pintores de su época, relacionado también con el entorno de los Reyes Católicos, Pedro Berruguete,

\footnotetext{
${ }^{29} \mathrm{En}$ varias ocasiones envió informes a los monarcas que influirían de forma muy directa en sus ánimos, como el titulado Las cosas que debían remediar los Reyes, caracterizado por una gran dureza.

${ }^{30}$ Sobre este tema, S. CABALlERo, El caso del Santo Niño de La Guardia, ob.cit.

${ }^{31}$ Daniel RICO CAMPS, La imagen de Pedro Arbués. Literatura renacentista y arte medieval en torno a don Alonso de Aragón, "Locus Amoenus", I, (1995), p. 107-119 y del mismo autor, El sepulcro de Pedro de Arbues y su contexto, "Boletín de Museo e Instituto "Camón Aznar»", LIX-LX (1995), pp. 169-203.

${ }^{32} \mathrm{No}$ fue el único caso. El viajero Münzer describe una capilla del convento de dominicas de Santa Catalina de Siena de la siguiente manera: "construida con inusitada magnificencia por la reina Isabel; todas sus paredes, desde el suelo hasta el techo, hállanse cubiertas de sambenitos de los marranos que sufrieron condena, incluso los de aquellos que fueron quemados: cada uno lleva escrito el nombre del que lo vistió...". Hemos tomado la cita de Aurora RUIZ MATEOS; Olga PÉREZ MONZÓN; Jesús ESPINO NuÑO, Las manifestaciones artísticas, José Manuel NIETO SORIA (Director) Orígenes de la Monarquia Hispánica: propaganda y legitimación (ca. 1400-1520), Madrid, 1999, p. 355, nota 98.

${ }^{33}$ ACSTA, Libro Becerro 1776. Cajón no $1, n^{0} 4$.
} 
a quien dictó detalladamente el programa iconográfico a representar, poniendo a su disposición un códice con las leyendas de los tres santos en el que el artista se inspiraría para pintar las distintas escenas ${ }^{34}$. Post, en su momento, identificó este códice con el ejemplar conservado en el convento de Santo Domingo el Real de Madrid ${ }^{35}$. Se trata de un códice titulado "Leyendas de Santo Tomás" encuadernado en pasta del S. XVII que contiene no sólo la leyenda del Santo de Aquino sino que se compone además de las leyendas de San Pedro de Verona y Santo Domingo de Guzmán y cantos de carácter litúrgico ${ }^{36}$. A diferencia de la teoría tradicional del padre Getino que fechaba estas últimas en el S. XIII y las de Santo Tomás en el S. XIV, Pedro Cátedra ha considerado que todas ellas formaron parte de un códice original compuesto en el primer tercio del S. XV copiado por Pedro Marín tal y como consta al final de la leyenda ${ }^{37}$ :

\section{Flagilis et ineptus \\ Congaudeat vestris precibus \\ Scriptor filius verus \\ Cujus nomen Martinus Petrus ${ }^{38}$.}

No es seguro que el ejemplar utilizado por Berruguete fuera el mismo que hoy se conserva en el convento madrileño escrito en romance, tal y como sugirió Post, pero, de no ser así, otro de similar contenido, y probablemente escrito en latín como correspondía a una comunidad masculina, engrosaba los fondos de la biblioteca de Santo Tomás y fue puesto a disposición del artista para llevar a cabo su encargo ${ }^{39}$.

\section{LAS IMÁGENES DE LOS SANTOS DOMINICOS EN SUS RETABLOS}

La iglesia del Convento de Santo Tomás fue depositaria de un gran número de obras antes de que la invasión napoleónica y el proceso desamortizador hicieran estragos en tan rico patrimonio. Pinturas, esculturas, libros,

\footnotetext{
${ }^{34}$ Para más detalles, S. CABALLERO, El Códice Medieval como fuente artística: Berruguete en Santo Tomás de Avila en Libros con Arte. Arte con Libros, Cáceres, 2007, pp. 147-159.

${ }^{35}$ Ch. R. Post, A History of Spanish Painting, ob.cit., p. 37. No sabemos si el autor señalado por Post es el predicador Pedro Marín, al que se le atribuyen algunos sermones conservados en la BNM fechados en torno a 1429. Sala Cervantes Mss. 9433.

${ }^{36}$ BNM. Sala General. Sign. 2/79975; L. GETINO, O.P. Origen del Rosario. Leyendas castellanas del S.XIII sobre Santo Domingo de Guzmán, Madrid, 1925, p. XVII.

${ }^{37}$ Pedro M. CÁTEDRA, Liturgia, poesía y teatro en la Edad Media, Madrid, 2005, p. 137.

${ }^{38}$ Luis GETINO, O.P. Leyenda de Santo Tomás de Aquino. Siglo XIV, Madrid, 1924. BNM. Sala General. Sign. 2/82̇558. Se trata de la edición del antiguo Códice, p. 7.

${ }^{39}$ Fray. Tomás de Torquemada fue el iniciador de la biblioteca conventual de Santo Tomás, donando, incluso algunos códices propios. La biblioteca original se dispersó perdiéndose algunos ejemplares, mientras que ottros se conservan hoy en bibliotecas nacionales y extranjeras. Para una aproximación Vid. Gregorio DE ANDRES, La colección de códices del convento de Santo Tomás de Avila en la Biblioteca Nacional de Madrid. Su identificación, "Hispania Sacra", año 41, (1989), p. 115.
} 
tapices y orfebrería lo convertían en uno de los edificios conventuales más importantes del tardogótico hispano.

La parte más importante de la iglesia, es decir, el altar, estaba presidida por tres importantes retablos pintados por Pedro Berruguete de los que únicamente conservamos uno en su espacio original, el retablo mayor dedicado al santo titular del templo, Santo Tomás de Aquino. Los dos restantes, dedicados a Santo Domingo de Guzmán y San Pedro Mártir de Verona respectivamente, están hoy expuestos en una de las salas del Museo del Prado. Sin embargo, a pesar de su distancia física actual, los tres fueron concebidos y diseñados en función de un mismo espacio y con una misma finalidad y, por ello, su análisis debe realizarse en ese sentido. La ubicación del Tribunal de la Inquisición en este edificio iba a pesar en cada uno de los encargos artísticos que allí tuvieran lugar y, en este sentido, la presencia de Santo Tomás de Aquino, santo intelectual que usaba su sabiduría para vencer a las herejías, Santo Domingo de Guzmán, fundador de la Orden más emparentada con la actividad inquisitorial, y San Pedro de Verona, inquisidor y mártir que murió asesinado por unos herejes, en el lugar más visible de la iglesia apuntaba en esta dirección.

\subsection{Santo Tomás de Aquino}

Captando la atención del visitante desde que entra en la iglesia, el retablo mayor se alza solemne sobre el altar elevado de la iglesia [Fig. 2]. Fue realizado por el pintor Pedro Berruguete siguiendo una estructura propiamente palentina $^{40}$. De acuerdo con las directrices del mentor iconográfico se eligieron una serie de escenas de la vida del Santo de Aquino que rodean la imagen del propio titular en la tabla central. Son cuatro las escenas representadas y siguiendo un orden cronológico se pueden identificar con las siguientes: la toma del hábito por el joven Santo Tomás (arriba a la izquierda del espectador), la tentaciones del santo (arriba a la derecha); Santo Tomás ante el crucifijo (abajo a la izquierda) y la aparición de San Pedro y San Pablo a Santo Tomás (abajo a la derecha). Todo ello completado con la presencia de ángeles en las entrecalles y San Esteban, San Agustín, San Juan Evangelista, un ángel con la Santa Faz, otro con la corona de espinas, San Mateo, San Jerónimo y San Sebastián en el banco.

Los tres retablos formaron una unidad iconográfica, sin embargo el retablo mayor ha sido interpretado en razón de un simbolismo humanista e intelectual que tendría cabida en un Convento en el que se estableció una Universidad $^{41}$. No obstante, mientras que las pinturas se realizaron a finales

\footnotetext{
${ }^{40}$ Otros ejemplos son el retablo de la Virgen en Santa María del Castillo o el de Becerril de Campos. J. YARZA, Berruguete, los escultores y la escultura en Pedro Berruguete. El primer pintor renacentista de la Corona de Castilla, ob. cit., p. 86.

${ }^{41}$ Hacia esta dirección apunta la opinión de Daniel Rico, como se deduce de sus palabras: "Se trata de la única obra mueble, en aquella especie de museo de la Inquisición, cuyo vector iconográfico no apunta directamente al Santo Oficio, sino a las otras dos grandes esferas de la vida dominicana, la espiritual y la intelectual”. Daniel RICO CAMPS, Imágenes del saber en
} 
del S. XV, el Estudio abulense no se fundó hasta 1504. Por este motivo, pensamos que la lectura debe ir en otra dirección, en clara relación con los sermones que allí tenían lugar y la audiencia que los iba a recibir.

El conjunto se halla presidido por la imagen de Santo Tomás de Aquino representado con el birrete de doctor como hombre de estudio [Fig. 3]. En una de sus manos porta una pluma, atributo alusivo a la condición intelectual del santo que dedicó varios de sus escritos al misterio de la Eucaristía. Su consagración al estudio de las Sagradas Escrituras y su sabiduría fue utilizado por la Orden de Predicadores como una de las principales armas para vencer a las herejías. Así, desde los comienzos, Santo Domingo de Guzmán otorgaba una gran importancia a los estudios teológicos como preparación fundamental para la predicación ${ }^{42}$. Era, precisamente, en la Universidad donde se formaron los adalides para triunfar sobre las herejías $^{43}$ y así se reflejó en las propias representaciones artísticas. En la Capilla Caraffa de la iglesia de Santa María sopra Minerva de Roma, centro inquisitorial, Santo Tomás fue representado por Filipino Lippi sobre los libros de los herejes y un personaje que sostiene el siguiente texto: Sapientia vincit malitiam $^{44}$.

Los mismos ángeles de las entrecalles portan libros abiertos o cerrados, algunos de los cuales contienen referencias a la principal obra de Santo Tomás, la Summa Theologicae. Propio del lenguaje artístico flamenco es jugar con la idea de realidad y ficción. Las figuras pintadas, tratadas como esculturas ubicadas en nichos y apoyadas en pedestales pero a la vez dotadas de movimiento y de las características propias de una persona viva, tienen una presencia constante en la pintura flamenca y sus derivadas. Una ambigüedad constante en la que el artista demuestra sus dotes al suprimir la frontera entre la realidad pictórica y la naturaleza. El factor de choque que se busca en el espectador, sin duda tuvo una razón de ser. Las esculturas en piedra permanecen, inmortalizan a los personajes representados. Las figuras vivas llevan aparejadas un carácter efímero. Precisamente ahí debe residir el efecto conscientemente buscado: representan dogmas y verdades teológicas que pasan por ser inmortales pero que hacen accesibles a los mortales.

Con la acción de apuntar con el dedo se pretende llamar la atención sobre el objeto, un gesto utilizado en la Edad Media para señalar el tema de una controversia ${ }^{45}$. El libro es el principal instrumento de la figura del predicador quien debía dominar las Sagradas Escrituras y la exégesis si quería vencer a los herejes. De hecho, en el primer Capítulo de Bolonia se revisó la

tiempos de los Reyes Católicos en Julio VALDEÓn BARUQUe (Ed.) Arte y cultura en tiempos de Isabel la Católica, Valladolid, 2003, p. 266.

${ }^{42}$ Humbert-Marie VICAIRE, Historia de Santo Domingo, Madrid, 2003, p. 452.

${ }^{43}$ Posteriormente en Trento, los escritos de Santo Tomás fueron utilizados como un arma contra los protestantes. Vid. Ficha de Luis VASALLO TORANZO en el catálogo de la exposición Las Edades del Hombre. Testigos, Catedral de Avila, mayo-noviembre de 2004, p. 229.

${ }^{44}$ Aurora PÉREZ SANTAMARÍA, Aproximación a la iconografía y simbología de Santo Tomás de Aquino, "Cuadernos de Arte e Iconografía", III/5, $1^{\circ}$ semestre, (1990), p. 34.

${ }^{45}$ Sixten, RingBOM, Les images de dévotion XII ${ }^{e}-X V^{e}$ siécle, París, 1995, p. 101. 
legislación de la Orden y se insertó un capítulo sobre el maestro de novicios, cuya misión era la de enseñar a aquéllos a leer o meditar sobre las lecturas de día o de noche, en casa o de camino. Era el principal elemento de estudio y debía ser la principal actividad de los frailes ${ }^{46}$. Los libros que aquí se representan aluden a la segunda y tercera partes de la Suma de Teología. Obra fundamental de la Escolástica fue escrita por Santo Tomás con un fin didáctico, a manera de manual de doctrina cristiana, con un lenguaje sencillo y asequible para poner al alcance de todos los asuntos más profundos de la $\mathrm{fe}^{47}$. La tercera parte de la obra contiene un Tratado del Verbo Encarnado, de la Vida de Cristo, de la Muerte y Exaltación de Cristo y de los Sacramentos; es decir, todos aquellos dogmas que la Iglesia defendía frente a la herejía.

Más elocuente y original es aún el segundo de los atributos con el que es caracterizado, una Sagrada Forma sobre un cáliz en el interior de un tabernáculo. No sorprende en manos de un defensor de la Eucaristía, pero debemos tener en cuenta, además, el significado de ese sacramento en el momento histórico que se estaba viviendo. Denostado por los judíos, se convirtió en el principal símbolo del cristiano. Por otro lado, no estaba lejos el caso del "Santo Niño de La Guardia". En aquel auto de fe, los judíos y conversos fueron condenados a la hoguera después de ser acusados de profanar una Hostia y el corazón de un niño cristiano para realizar rituales con el fin de exterminar a los inquisidores. Pero es más, un cronista de la Orden informaba en el S. XVII que los Reyes Católicos habían donado una Hostia que habían intentado profanar unos judíos de La Guardia, siendo consagrada en 1488, antes del auto celebrado en 1491:

"La Hostia consagrada fue tomada con gran reverencia y llevada por orden de los Reyes Católicos y los inquisidores fue puesta en el Sagrario del Altar Mayor del Real Monasterio de Santo Tomás donde hoy se ve..."48.

Esta reliquia fue conocida en su época como "Sacramento de los Herejes" y custodiada en una cajita de nácar que la princesa Margarita donó con este $\mathrm{fin}^{49}$.

El hecho de que sea mostrada por Santo Tomás exalta uno de los principales sacramentos de la Iglesia Católica, como es la Eucaristía, y que más polémica había suscitado entre la clase judía llevando a muchos de sus miembros a la hoguera bajo la acusación de prácticas relacionadas con este hecho. Los milagros eucarísticos y las historias sobre Hostias profanadas

\footnotetext{
${ }^{46}$ Simon, Tugwell, Santo Domingo, edición revisada, Strasbourg, 1996, p. 47.

${ }^{47} \mathrm{La}$ importancia que el texto tuvo entre los dominicos se puede comprobar al constatar el gran número de ejemplares que se encargaron en el S. XV. Fue además el texto básico de los dominicos salmantinos en el S. XVI. Vid. Ficha de Pilar RODRÍGUEZ MARÍN, Summa Theologicae. Secundae Partis, Pars Secunda, 1479, Catálogo de la exposición Las Edades del Hombre, ob.cit., p. 239.

${ }^{48}$ ACSTA, Datos históricos para la historia de este convento de Santo Tomás de Ávila, Cajón 27. Carp. 14, $27 / 16$.

${ }^{49}$ ACSTA, "Trozos tomados del ms. Que me ha prestado el Sr. Marqués de Piedras Albas y Benavites y que perteneció a este convento de Santo Tomás... Noticias de las cosas memorables de la fundacion de este Real Convento de Santo Tomás de Avila, está sacada de los Instrumentos originales que hay en su archivo", $27 / 33$.
} 
sirvieron a los predicadores como instrumento de convencimiento ${ }^{50}$. Por otro lado, una de las características que definían a los herejes era su comportamiento en la Misa, en el momento más culminante de ésta, es decir, el de la consagración ${ }^{51}$, realizando gestos obscenos y desviando la vista hacia el muro.

Pero los guiños a las circunstancias históricas que se estaban viviendo no se quedan ahí. Esa especie de casquete que lleva Santo Tomás, no sólo caracterizaba a los doctores sino que también distinguía a los inquisidores. Así es caracterizado Pedro de Arbués, inquisidor de la Corona de Aragón, en su primera lápida funeraria. Bien es cierto que Santo Tomás no ocupó ningún cargo en el Santo Oficio aunque sí legitimó la existencia de la Inquisición en más de una ocasión ${ }^{52}$. Por otro lado, aunque la tabla fue alterada en el S. XVIII, añadiendo un repinte que ocultaba el auténtico fondo para dar un aspecto escultural a la imagen de Santo Tomás, aún se pueden apreciar las esquinas del dosel que, del mismo modo que en las tablas de los titulares de los retablos de Santo Domingo y San Pedro Mártir, cubría a Santo Tomás. El dosel remitía a la ceremonia de los autos de fe, en los que sólo la tribuna de los inquisidores se distinguía por este elemento ${ }^{53}$.

De lo anterior se deduce que el mentor del programa tuvo que ser alguien de una gran cultura que conoció desde dentro la Orden de Predicadores y los símbolos y el modo de obrar del Santo Oficio. Tomás de Torquemada cumplía todos estos requisitos ${ }^{54}$.

\subsection{Santo Domingo de Guzmán}

Al fundador de la Orden de Predicadores se le dedicó uno de los retablos colaterales situados en el crucero a ambos lados del Altar Mayor. De acuerdo con la descripción que ofrecen los textos, ocupó el lado del Evangelio, mientras que el lado de la Epístola fue reservado para el retablo de San

\footnotetext{
${ }^{50}$ Paulino RoDRÍGUEZ BARRAL, Eucaristía y antisemitismo en la plástica gótica hispánica, "Boletín del Museo e Instituto «Camón Aznar», XCVII (2006), pp. 279-348

${ }^{51}$ J.C. SCHMitT, La raison des gestes dans l'Occidente Médiéval, París, 1990, p. 308. Circulaban muchas historias de este tipo como la del prior del monasterio jerónimo de la Sisla en la que el padre García Zapata durante la celebración de la fiesta de los Tabernáculos, en el momento de la elevación, pronunciaba frases blasfemas en vez de las palabras de la consagración. Su destino sería la hoguera convirtiéndose en una de las primeras víctimas de la Inquisición. Joseph PÉREZ, Breve historia de la Inquisición en España, Barcelona, 2003, p. 22.

52 “Bajo ningún concepto se puede ser indulgente con los herejes. La compasión llena de amor de la Iglesia permite ciertamente que sean amonestados, pero caso de que se muestren obstinados, tiene que entregarlos al brazo secular para que la muerte les saque de este mundo... Por eso tambiẹn el hereje arrepentido es siempre admitido a penitencia y por eso se le respeta la vida. Pero si se convierte en relapso, puede en verdad acceder a la penitencia para el bien de su alma, pero no puede librarse de la pena de muerte", en José BELMONTE, Judíos e Inquisición en Avila, Ávila, 1989, p. 131.

${ }^{53}$ Joseph PÉREZ, Breve historia, ob.cit., p. 144.

${ }^{54}$ Aunque por falta de espacio no lo podemos desarrollar hay que tener en cuenta el tipo de público al que iban dirigidas las obras. Igual que ocurría en el ámbito de los sermones, trabajados de un modo ambivalente para que pudieran servir a varias clases de oyentes, en el campo de las artes, y en este caso en concreto podemos decir que el retablo mayor, dada la selección de los temas elegidos y su tratamiento, iría encaminado también a los frailes dominicos, predicadores y responsables de la lucha contra la herejía. S. CABALLERO, Función y recepción de las artes plásticas en el S. XV, "Norba Arte", XXVI (2006), pp. 19-31.
} 
Pedro Mártir, al que aludiremos más tarde. Ambos se rodearon de las sentencias y sambenitos de los condenados que, colgados en el muro, causarían, sin duda, una honda impresión en el público asistente:

\section{Las sentencias de los quemados que son lienzo están en el colateral del lado del Evangelio, que es un altar de Santo Domingo glorioso...los ensambeni- tados...están al colateral de la Epístola que es un altar de San Pedro Mártir...5}

Pero, al menos desde el S. XVIII, las tablas pertenecientes a sendos retablos estuvieron situadas en el claustro alto -probablemente el principalde dicho Convento, tal y como nos informa D. Antonio Ponz en su "Viaje a España" ${ }^{56}$, la misma ubicación que señalaba Villaamil en 1865 cuando vio los marcos de yeso en los que estaban insertadas en el piso superior del Claustro de los Reyes ${ }^{57}$. Incluye, además, una interesante noticia sobre el número de pinturas que se mostraban, doce, un dato que no coincide con el ofrecido por la documentación elaborada por la Comisión de Monumentos referente a los conventos suprimidos en la Desamortización donde se alude a "catorce pinturas en tabla que se hallaban en los claustros de dicho convento" 58 .

El número de pinturas sobre tabla que se conservan en la actualidad en el Museo del Prado procedentes del convento abulense son once, por lo tanto habría que tener en cuenta las obras desaparecidas, de alguna de las cuales daremos cuenta en las siguientes líneas.

El traslado de los retablos al claustro trajo como consecuencia su desintegración, perdiéndose la arquitectura original que los conformaba así como el orden de las tablas. No obstante, su estructura se acercaría bastante a la del retablo mayor, es decir, constarían de un banco y tres calles separadas por entrecalles, con dos cuerpos ocupados por una tabla a cada lado, a excepción de la calle central que estaría presidida por el santo titular rematado por tres pináculos [Fig. 4].

La tabla correspondiente al santo titular, Santo Domingo de Guzmán, tiene un desarrollo similar a la de Santo Tomás en el retablo mayor y San Pedro Mártir en el colateral. El dominico aparece revestido con su hábito en un interior cubierto con dosel y distinguido con su atributo habitual, los lirios en alusión a la pureza [Fig. 5]. Pero, además, porta un báculo en forma de cruz que clava sobre un animal de formas caninas envuelto en llamas. Un detalle presente en la propia portada de la iglesia de Santo Tomás y en otro de

\footnotetext{
${ }^{55}$ ACSTA, Libro Becerro de 1776. Cajón n ${ }^{0}$ 1, no 4.

${ }^{56}$ Antonio, PonZ, Viaje de España, Tomos IX-XIII, Madrid, 1988 (MDCCLXXXVI), p. 715.

${ }^{57}$ Cruzada VILlaAmIL, Catálogo provisional del Museo Nacional de Pinturas, 1865, p. 182. A excepción del retablo mayor conservado in situ, durante la desamortización de 1836 fueron trasladados al Museo de la Trinidad, cuyos fondos constituirían posteriormente los del Museo del Prado.

${ }^{58}$ Archivo de la Real Academia de Bellas Artes de San Fernando (en adelante ARABASF), Conventos suprimidos. Ávila. 35-13/1. Convento de Santo Tomás, f. 1.
} 
los monumentos relacionados con fray Tomás de Torquemada, la iglesia del Convento de la Santa Cruz de Segovia [Fig. 6].

Santo Domingo es presentado como "enquisidor", así lo indica la inscripción incluida en la aureola que rodea su cabeza. Algunos historiadores como Post, Eduardo Carrero o Joaquín Yarza resaltaron esta peculiaridad iconográfica, relacionándola con las intencionalidades subyacentes del mentor del programa, fray Tomás de Torquemada ${ }^{59}$. De este modo, haciendo gala de un clara manipulación de las imágenes, llegando a falsificar la historia al colocar a Santo Domingo a la cabeza del Santo Oficio, se utilizó el prestigio del fundador de la Orden, presentándolo como un antecesor en el cargo de inquisidor y legitimando, de este modo, el tribunal que Torquemada presidía.

Esta vinculación de Santo Domingo con la Inquisición debió de ser un recurso utilizado con cierta ligereza en el campo de las artes plásticas hispanas. Un ejemplo es el Santo Domingo del Museo del Bellas Artes de Córdoba de Pedro de la Romana (1488-1536) que contiene la inscripción "Haeretica Pravitas" $"$.

La herejía es, por tanto, asociada a un animal de características caninas $^{61}$. La tradición remonta siglos atrás y no es exclusiva del ámbito hispano, tal y como comprobamos en el Bestiario Moralizado de Guillaume le Clerc (h. 1260) en el que los judíos son representados como una hiena, un animal que según el texto "simboliza a los hijos de Israel, que al principio creyeron en el verdadero Padre omnipotente pero que renunciaron a él y fueron tan insensatos que adoraron ídolos" ${ }^{\text {"2 }}$; o el caso de Jean Alard, en el París del S. XIII, que fue acusado de mantener relaciones con una mujer judía, siendo ambos condenados a la hoguera "porque el coito con una mujer judía es exactamente igual a que un hombre copule con un perro" $" 3$.

Así, una alegoría relacionada con la orden dominica será la lucha de los perros del Señor, los "domini canes", contra los lobos de la herejía, como aparece en la portada de la Santa Cueva de Segovia o, fuera de nuestras fronteras, en el convento de Santa María Novella o en la tabla de Francesco Traini del Museo de San Mateo de Pisa que representa la disputa de Santo Domingo con un grupo de cátaros figurándose a los pies los perros y lobos.

Los conversos fueron acusados de hipocresía y falsa $\mathrm{fe}^{64}$. Así surgieron tratados como el "Libro o Tratado del Alboraique" en los que se

${ }^{59}$ Ch.R. POST, A History, ob.cit., p. 36; E. CARRERO, Patrocinio regio e Inquisición, ob.cit., p. 458; J. YARZA, Una imagen dirigida, ob.cit. p. 39.

${ }^{60}$ Citado por Joaquín YARZA, Una imagen dirigida, ob.cit., pp. 25-54.

${ }^{61} \mathrm{El}$ carácter negativo del lobo como personificación del mal, se encuentra ya en la Biblia, Mateo 10, 16.

${ }^{62} \mathrm{Michel} \mathrm{CAMILLE}$, El ídolo gótico. Ideología y creación de imágenes en el arte medieval, Madrid, 2000, p. 183 .

${ }^{63}$ Ibídem, p. 188.

${ }^{64}$ Ya desde el S. XIII aparecieron escritos antijudíos en Castilla. Vid. J. VALDEÓN, Judíos y conversos, ob.cit., p. 46. Por otro lado se escribieron un gran número de obras, como él Cancionero de Baena, las Coplas de Mingo Revulgo o las Coplas del Provincial que reflejan muy bien esa hostilidad hacia el grupo converso. 
fustigaba a los conversos ${ }^{65}$. Su autor, tal vez un converso, se refiere a los cristianos nuevos que no eran ni judíos ni cristianos y los compara con el alboraique que relacionaba con el corcel que el arcángel Gabriel regaló a Mahoma sin una forma definida, sin ser caballo ni mula, macho ni hembra ${ }^{66}$. En las páginas que componen este libro se describe las peculiaridades del alboraique y se les aplica a los "falsos cristianos":

\begin{abstract}
Alboraique tenía boca de lobo y así la tenían los marranos, pues eran hipócritas y falsos profetas. Alboraique tenía orejas de galgo, y los marranos eran perros, pues volvían a lamer el vómito de su sabbath. Comía toda clase de cosas y los marranos comían manjares moros y cristianos y nunca ayunaban... ${ }^{67}$.
\end{abstract}

La referencia a los animales y la utilización de alegorías para clarificar el contenido de ideas complejas y para fomentar el recuerdo fueron muy utilizados en el campo de la homilética ${ }^{68}$. Los sermones se componían de exempla, similitudines y pláticas y la recurrencia a los animales para hacer más asequible el contenido de los sermones a un público poco instruido era frecuente. Así se recomendaba en las Ars Praedicandi como es el caso de Martín de Córdoba quien animaba a utilizar referencias a animales para hacer comprensibles los contenidos más transcendentes ${ }^{69}$.

La utilización de la imagen de Santo Domingo en un contexto inquisitorial se da también en otras dos obras significativas procedentes del convento y hoy custodiadas también por el Museo del Prado. Me estoy refiriendo al conocido "Auto de Fe", atribuido a Pedro Berruguete, y a la "Virgen de los Reyes Católicos", analizados en otro lugar" ${ }^{70}$.

Aunque la primera tentativa ha sido considerar el Auto de $\mathrm{Fe}$ como parte integrante del retablo de Santo Domingo no coincide ni en medidas ni en formato con éste [Fig. 7]. Villaamil indica en su catálogo de pinturas del Museo del Prado de 1865 que hacía pareja con otra tabla de tema inquisitorial y que ambas piezas flanqueaban a la "Virgen de los Reyes Católicos". La tabla que falta fue vendida y trasladada a Londres, donde no sabemos si aún se conserva entre los fondos de alguna colección particular o se destruyó ${ }^{71}$.

\footnotetext{
${ }^{65} \mathrm{Su}$ cronología no es segura pero es aceptada generalmente la de 1488. Agustín BUSTAMANTE GARCíA, Alboraique. Un dato iconográfico, "Archivo Español de Arte", 280 (1997), p. 420.

${ }^{66}$ T. Hope, Torquemada, Buenos Aires, 1944, p. 123.

${ }^{67} \mathrm{BNM}$, Historia de las comunidades de España sacada de la crónica del emperador Carlos Quinto, escrita por Pedro Mexía su cronista/Item libro llamado el Alboraique, Sala de Manuscritos, Mss. 17.891.

${ }^{68}$ P.M. CÁTEDRA, Los sermones atribuidos a Pedro Marín. Van añadidas algunas noticias sobre la predicación castellana de San Vicente Ferrer, Salamanca, 1990, p. 35, nota 27.

${ }^{69}$ Manuel Ambrosio SÁNCHEZ SÁNCHEZ, Los Bestiarios en la predicación castellana medieva, "Actas del III Congreso de la Asociación Hispánica de Literatura Medieval”, Tomo II (Salamanca 3-6 de octubre de 1989), Salamanca, 1994, pp. 915-921.

${ }^{70}$ Vid. S. CABAllero, La Virgen de los Reyes Católicos: escaparate de un poder personal e institucional, "Reales Sitios", XLIV/173, (tercer trimestre de 2007), pp. 20-42.

${ }^{71}$ Ch.R. POST, A History, ob.cit., p. 59.
} 
Una vez más, Santo Domingo es vinculado directamente con el Santo Oficio, en este caso presidiendo un auto de fe y remitiendo a un suceso histórico reciente ocurrido en Ávila y que tanta repercusión iba a tener en la historia de España, el auto de fe celebrado en Ávila en el que fueron castigados los herejes acusados de asesinar al Niño de La Guardia ${ }^{72}$. No se trata del Auto en sí celebrado en Ávila pero sí es una referencia indirecta a este acontecimiento tan crucial y determinante para la futura expulsión. El hecho de que la imagen de Santo Domingo esté presidiendo el acto viene a legitimar la manera de actuar del Santo Oficio en su lucha contra la herejía.

El retablo de Santo Domingo se componía de otras tablas en las que se representaban algunos episodios de su vida como es el caso de la "Prueba del Fuego", la "Resurrección de Napoleón Orsini", la "Aparición de la Virgen a una comunidad" y la "Adoración de su sepulcro", esta última considerada por algunos autores como tabla integrante del retablo de San Pedro Mártir ${ }^{73}$.

No es el momento de detenernos en el análisis concreto de cada una de las tablas pero sí de señalar la relación que presentan muchas de ellas con el momento que se estaba viviendo. Como hemos dicho, los pasajes no fueron elegidos al azar y un tema como el de la quema de libros de los herejes, episodio milagroso narrado en la vida de Santo Domingo, adquiría plena actualidad a finales del S. XV.

La tabla representa el acontecimiento narrado en el capítulo XIII del Códice de Santo Domingo el Real de Madrid, texto que hemos considerado como la fuente principal de los retablos de Santo Tomás. En él Santo Domingo se enfrenta a un grupo de herejes, echando en el fuego sus escritos para demostrar la verdad de su fe; salen indemnes a diferencia de los pertenecientes a los herejes que arden en el fuego. Pero, lo más importante, es que se trata de un episodio que se puede relacionar con el momento histórico en el que se produce el encargo. El mentor iconográfico, que identificamos con Torquemada, ha aprovechado las posibilidades del tema para aludir subliminalmente a un acontecimiento que formó parte de la vida cotidiana del Santo Tribunal. La quema de libros era una práctica habitual también en Ávila. Tenemos constancia de actuaciones de este tipo incluso antes de que se estableciera el Santo Oficio en Castilla. Juan II de Castilla encargó a fray Lope de Barrientos, obispo de Ávila, quemar los libros del Arte Mágica de Enrique de Villena, tal y como cuenta en su Tratado de las Especies de Adivinança: quémolos por obediença en presencia de algunos

\footnotetext{
${ }^{72}$ Para más detalles, S. CABALLERO, El convento de Santo Tomás de Ávila: Santo Tomás de Aquino, Santo Domingo de Guzmán y San Pedro Mártir, adalides de la propaganda inquisitorial, Isabel la Católica y su época, vol. II, Valladolid, 2007, pp. 1283-1313; Idem, El caso del Santo Niño, ob.cit.

${ }^{73}$ Por poner un ejemplo Pilar SiLva MAROTO, Ficha técnica del Catálogo de la exposición Pedro Berruguete, ob.cit., p. 194.
} 
servidores regios... ${ }^{74}$. En el año 1490 y en una ciudad cercana como Salamanca ardieron libros de arte, ciencia, magia...todos ellos confiscados a judíos y conversos. Aparte de testimoniar la licitud de una práctica que fue dirigida por el fundador en su enfrentamiento con los albigenses, se exalta el valor del libro como portador de la doctrina de la fe frente a los textos heréticos.

Pero las alusiones a las herejías amenazantes no acaban ahí. En la tabla que representa la aparición de la Virgen a una comunidad se muestra un acto devocional de una comunidad de frailes dominicos en un interior conventual. El hecho de que, en apariencia, no tenga nada que ver con la vida de Santo Domingo ha creado dudas sobre la pertenencia o no a este retablo. Sin embargo, a través de un arco se vislumbra un claustro cuya arquitectura, al igual que en el resto de las tablas, remite a la propia del convento abulense, un recurso para acercar las escenas a los fieles. En una de las galerías un fraile lucha por escapar del ataque del demonio, ajeno a las oraciones que el resto de la comunidad dirige a la Virgen. La escena recuerda a un episodio posterior a la muerte del Santo y recogida por su biógrafo Gerardo Frachet en el que un fraile de Bolonia es poseído por el diablo, debido a lo cual se organiza el canto de la Salve por el resto de la comunidad ${ }^{75}$. Por su parte, Jordán de Sajonia relata la visión de la Virgen durante el canto de la Salve por parte de los religiosos en su Capítulo de Montpellier (1247). Después de las Completas los rociaba a todos y los saludaba amorosamente ${ }^{76}$.

Santo Domingo ha sido considerado el fundador del Rosario, así lo han manifestado varios Papas, como es el caso de San Pío V: "Según se cree piadosamente, Santo Domingo, inspirado por el Espíritu Santo, encontrándose en circunstancias análogas a las de nuestros días, en las cuales los albigenses vejaban Francia y la Italia...buscando un modo sencillo de orar al Señor, concibió como más fácil el Rosario o Salterio de la Virgen María". O Pío IX: "...le sirvió para quebrantar la nefasta herejía de los albigenses" "77. Y me interesa especialmente esta última cita. El Rosario es una oración sencilla que tuvo un gran éxito entre el público popular. De hecho, dada su facilidad para ser recordada, pudo ser el tema de la predicación de Santo Domingo en el sur de Francia para hacer frente a la herejía albigense ${ }^{78}$.

El Santo Rosario fue el principal tema de la predicación del fundador para eliminar la herejía albigense. La Virgen María ejercía una especial protección entre los devotos de la orden dominica y hacía ella dirigían letanías para obtener su auxilio. Su reflejo iconográfico está de manifiesto en esta tabla

\footnotetext{
${ }^{74}$ Cándido $\mathrm{M}^{\mathrm{a}}$. AJo GonZÁlez DE RAPARIEGOS, El Siglo XV: primer Siglo de Oro abulense, - Historia de Avila y de toda su tierra, de sus hombres y sus instituciones, por toda su geografia provincial y diocesana, Centro de Estudios e Investigaciones ascético-místicos histórico-biblicos y literarios, Salamanca, 1994, p. 943.

${ }^{75}$ J. YARZA, Una imagen dirigida, ob. cit., p. 44.

${ }^{76}$ Beato JoRDÁn DE SAJONIA, Vida de Santo Domingo de Guzmán, traducción y notas del P. Getino, Vergara, 1916, p. 100.

${ }^{77}$ Ibídem.

${ }^{78}$ Miguel Ángel FUERTES, El Rosario: oración de ayer y de hoy, Salamanca, 1993, p. 36.
} 
y en la que se conserva en el convento de Santa Catalina de Utrecht del S. XVI, muy próxima a la que analizamos, como ya puso de manifiesto Joaquín Yarza $^{79}$. Era una forma de manifestar la devoción mariana de los dominicos y la protección de la que gozaban. Siendo la orden más vinculada a la Inquisición y utilizando el nombre de la Virgen en su lucha frente a la herejía, su pertenencia al retablo de Santo Domingo en la iglesia de Santo Tomás, sede de la Inquisición y asiento, a su vez, de una cofradía de Nuestra Señora del Rosario, haría muy probable esta teoría.

\subsection{San Pedro Mártir de Verona}

San Pedro Mártir nació en la ciudad de Verona en el seno de una familia de condición cátara. Tal y como nos informa su principal biógrafo Gerardo de Frachet, el niño pertenecía a una familia cuyos miembros casi todos eran herejes ${ }^{80}$. Por propia iniciativa decidió ingresar en la Orden, buscando al mismo fundador Santo Domingo ante el que se postró pidiéndole que le admitiera como discípulo. Tomó el hábito en 1221 y destacó por ser un ferviente predicador, distinguido por su elocuencia gracias a lo cual consiguió la conversión de toda la región de la Toscana.

Pero no sólo era predicador sino que, a diferencia de su maestro, también fue juez apostólico y uno de los primeros inquisidores. En 1232 el Papa Gregorio IX le había nombrado inquisidor general de Italia ${ }^{81}$. Esta condición y las circunstancias dramáticas de su muerte fueron una de las razones que llevaron a Torquemada a la dedicación de uno de los retablos principales de la iglesia del Convento de Santo Tomás.

Cuando se dirigía de Como a Milán, después de una de sus predicaciones junto a su compañero fray Domingo, fue asaltado por dos herejes llamados Carín y Auberto. Carín, escondido en el bosque, sorprendió a San Pedro clavándole una hoz en la cabeza mientras fray Domingo recibía una serie de puñaladas que le provocarían días después la muerte. Comprobando que San Pedro había quedado malherido, le remataron clavándole un puñal en el pecho. Antes de morir, escribió con su propia sangre las primeras palabras del Credo.

Torquemada se valió del pasado prestigiado actualizándolo de tal manera que se pudiera aplicar al momento que estaban viviendo. El propio cargo de inquisidor de San Pedro y las circunstancias violentas de su muerte a manos de unos herejes permitía una comparación con los hechos de finales del S. XV, cuando los judíos y conversos de Zaragoza fueron acusados de asesinar al inquisidor de la Corona de Aragón, Pedro de Arbués, en 1485. Esa muerte violenta sobrecogió a la población de tal manera, que los sentimientos de odio se volvieron hacia la clase judía a la que apuntaban como responsable

\footnotetext{
${ }^{79}$ J. YARZA, Una imagen dirigida, ob.cit., p. 44.

${ }^{80}$ Fr. Salvador VelaSCO O.P., San Pedro de Verona, Guadalajara, 1981, p. 3.

${ }^{81}$ Ibídem, p. 54.
} 
del suceso. Esta situación fue aprovechada hábilmente por la Inquisición como arma para exaltar los ánimos del pueblo y buscar el máximo apoyo a su causa. La ira, dirigida hasta entonces contra los inquisidores, considerados como una amenaza contra sus fueros y autonomía, se lanzó contra los asesinos de Arbués y, por extensión, contra el grupo de conversos y la clase judía. Por tanto, el asesinato de su inquisidor en 1485, unido al culto que se le daría a raíz de su muerte, fue determinante para la consolidación del Santo Oficio en Aragón ${ }^{82}$.

Por tanto, la elección del programa iconográfico del tercero de los principales retablos de la iglesia dedicado a San Pedro de Verona permitía exaltar el odio hacia aquellos que se encontraran fuera de la doctrina de la Iglesia Católica, en ese momento los judíos, y justificarlo recurriendo a hechos del pasado que tuvieran vinculación con el presente y a la vez lo prestigiaran.

El retablo estaba situado en el crucero, en el lado opuesto al de Santo Domingo, y, como este último, hoy está desintegrado formando parte de la colección del Museo del Prado. Su estructura, probablemente, seguía la del mayor, con un banco, una tabla central dedicada al titular y una calle lateral, a un lado y otro respectivamente, con escenas de su vida y muerte.

La tabla principal tiene una disposición similar a la que centraba el retablo de Santo Domingo de Guzmán, también conservada en el Museo del Prado. San Pedro ocupa el primer plano en un interior cubierto con el dosel que también aparece en las tablas de Santo Tomás de Aquino y Santo Domingo, detalle que recuerda a los autos de fe en que este mismo elemento cubría la tribuna de los inquisidores. La resolución espacial de esta tabla demuestra el dominio del pintor Pedro Berruguete a la hora de lograr la sensación de perspectiva, muy superior a los pintores hispanos de su época. La profusión de dorados ayuda a sacralizar aún más a la figura y mediante la apertura hacia un paisaje en los laterales de la tabla rompe el carácter monótono de la misma.

El santo se reviste con el hábito propio de la Orden y distinguido con los atributos comunes alusivos a su martirio, el hacha en su cabeza y el cuchillo en el pecho. Su condición de confesor, mártir y virgen es acentuada mediante la palma con las tres coronas [Fig. 8]. Los acontecimientos recientes de Zaragoza llevaban al espectador a establecer una conexión imaginaria entre el mártir de Verona y San Pedro de Arbués. Ambos estaban ligados no sólo por tener un mismo nombre sino también por la pertenencia a la orden dominica, su cargo de inquisidores y las características de su muerte. El martirio de ambos favorecía la repulsa de la población cristiana hacia los judíos, a quienes acusaban de la muerte de Jesucristo, de crímenes rituales -como el del Santo Niño de La Guardia- y del asesinato del inquisidor de

\footnotetext{
${ }^{82}$ D. RiCO, La imagen de Pedro Arbués, ob.cit. El paralelismo que se estableció entre San Pedro de Verona y San Pedro de Arbués fue utilizado incluso en los sermones, como el del inquisidor.Martín García en su sermón XXIX. También en su lápida fụneraria en la que aparece con los mismos atributos que el santo de Verona. Vid. D. RICO, La imagen de Pedro Arbués, ob.cit., p. 116 , nota 36 .
} 
Zaragoza Pedro de Arbués. De ese modo, se fomentaba la crispación en las masas y a ello contribuían no sólo los sermones de algunos frailes sino también las representaciones artísticas.

El resto de las tablas que lo completaban representaban hechos milagrosos, como el conocido "milagro de la nube" 83 , experiencias religiosas del santo como la escena que protagonizó frente a un crucificado o el momento de su martirio a manos de unos cátaros. Algunos autores han considerado que también perteneció a este retablo la adoración del sepulcro, tabla que, coincidiendo con la teoría de Joaquín Yarza, hemos vinculado al retablo de Santo Domingo ${ }^{84}$.

Una vez más, todas las escenas elegidas tenían plena actualidad a finales del S. XV. En el "milagro de la nube" San Pedro fue retado públicamente por un "obispo de los herejes" en un día muy caluroso en la ciudad de Milán a interponer, milagrosamente, una nube entre ellos y el sol para sofocar el excesivo calor. El episodio es narrado con todo detalle en el códice madrileño, que hemos considerado como fuente, y tal y como está representado coincide con aquellas disputas dialécticas entre predicadores y herejes tan comunes a finales de la Edad Media. No es el momento de extendernos en el análisis profundo de cada una de las tablas pero, a favor de nuestra tesis, destacamos la introducción de algunos detalles que convierten este episodio del pasado en una escena del presente inmediato. La ambientación de la propia escena parece tener lugar en una plaza castellana en la que la iglesia del fondo recuerda a la de San Pedro de Ávila ubicada en la plaza de Santa Teresa de esta ciudad. No sería extraño si atendemos a la localización del resto de las escenas componentes de los tres retablos, en las que se han representado estancias conventuales similares a las propias del Convento de Santo Tomás de Ávila. De ese modo, se pretendía establecer un guiño al presente desde escenas que acontecieron en el pasado para inmiscuir al espectador de una forma más eficaz.

Pero, sin duda, la tabla más dramática es la del martirio. Se representa el momento en que San Pedro, herido de muerte, escribe las

\footnotetext{
${ }^{83}$ Antes de su restauración la escena fue identificada como una de las múltiples predicaciones llevadas a cabo por el santo en las plazas de las ciudades buscando la conversión de los fieles. Era éste el escenario habitual puesto que, dada la fama de su oratoria, el número de asistentes era tan elevado que las iglesias se quedaban pequeñas, tal y como relatan las distintas biografías. La restauración llevada a cabo hace unos años en el Taller del Museo del Prado permitió a María Alvarez-Garcillán levantar los repintes que ocultaban el verdadero tema del cuadro. Se trata del Milagro de la nube, uno de los numerosos episodios milagrosos que transcurrieron en sus predicaciones. La restauración fue realizada por María Teresa Dávila, María Alvarez-Garcillán, María Antonia López de Asiaín y Almudena Sánchez a fin de que pudiera mostrarse en la exposición de Paredes de Nava organizada con motivo del V Centenario de la muerte del pintor. Catálogo de la exposición Pedro Berruguete, ob.cit., $\mathrm{p}$. 188. Más datos sobre el proceso de restauración, Maria ALVAREZ GARCILLAN, Unas obras de Berruguete recuperadas en el Museo del Prado, "Actas del Simposium Internacional" Pedro Berruguete y su entorno, ob.cit., pp. 435442.

${ }^{84}$ Las razones están expuestas en nuestra Tesis Doctoral Las artes plásticas del S. XV en Ávila, defendida en la Facultad de Geografía e Historia de la Universidad de Salamança el 4-9-2007 y dirigida por la profesora $\mathrm{D}^{\mathrm{a}}$ Lucia Lahoz, a quien agradecemos la revisión crítica de este texto y sus sugerencias. Tesis inédita.
} 
palabras del Credo con su propia sangre mientras el hereje se dispone a rematarlo con una puñalada que le atraviesa el corazón.

La elección de este tema para completar el retablo de San Pedro no dejaría indiferente a nadie. La historia de San Pedro de Verona se había repetido recientemente en Zaragoza con la muerte de Pedro de Arbués, inquisidor de la Corona de Aragón asesinado por unos herejes en la Seo de la ciudad. Las condiciones en que se produjo su muerte y el consecuente proceso sacralizador de su figura -elevada a la categoría de mártir de la fe-, dirigido por el propio rey Fernando el Católico, provocó un vuelco en la actitud de las masas que, hasta ese momento, habían rechazado firmemente el establecimiento del Tribunal en la Corona de Aragón. Instrumentalizando la muerte de Pedro de Arbués y estableciendo un nexo de unión con Pedro de Verona, legitiman las bases de una institución que es aceptada, a partir de entonces, como el mejor mecanismo de salvaguarda de la Fe Católica. Presentando a las figuras más prestigiosas y populares de la Orden de Predicadores ante el público, Torquemada influye en la opinión popular acallando todo tipo de críticas e incentivando el odio hacia los causantes de esos crímenes injustos.

No debemos olvidar que los tres retablos se mostraban rodeados de los sambenitos colgados en los muros. Simbolizaban el triunfo de la Iglesia sobre la herejía y era un recuerdo constante de la insidia judía.

No ha sido nuestra pretensión realizar un análisis detallado de cada una de las tablas que compusieron los retablos sino destacar, de una manera global, la utilización de las imágenes de los tres santos principales de la Orden con unos fines muy concretos. Los lazos, reales o imaginados, con el contexto histórico e inquisitorial son evidentes. Más allá de ser el resultado de una elección espontánea, los episodios representados ahondan en valores como la defensa de la ortodoxia católica frente a las herejías, la oración, la predicación, la Eucaristía, en definitiva, pasajes de las vidas de los tres santos de plena actualidad en el momento en que se encargaron las pinturas. De ese modo, el espectador se sentiría identificado con lo que allí veía.

Una vez más, las imágenes no fueron sujetos pasivos que surgieron a la sombra de la historia, sino sujetos activos y parlantes, provocadores de actitudes y creencias y, a su vez, transmisores del sentir de una época.

Fecha de recepción del artículo: enero 2008.

Fecha de aceptación y versión final: diciembre 2008. 


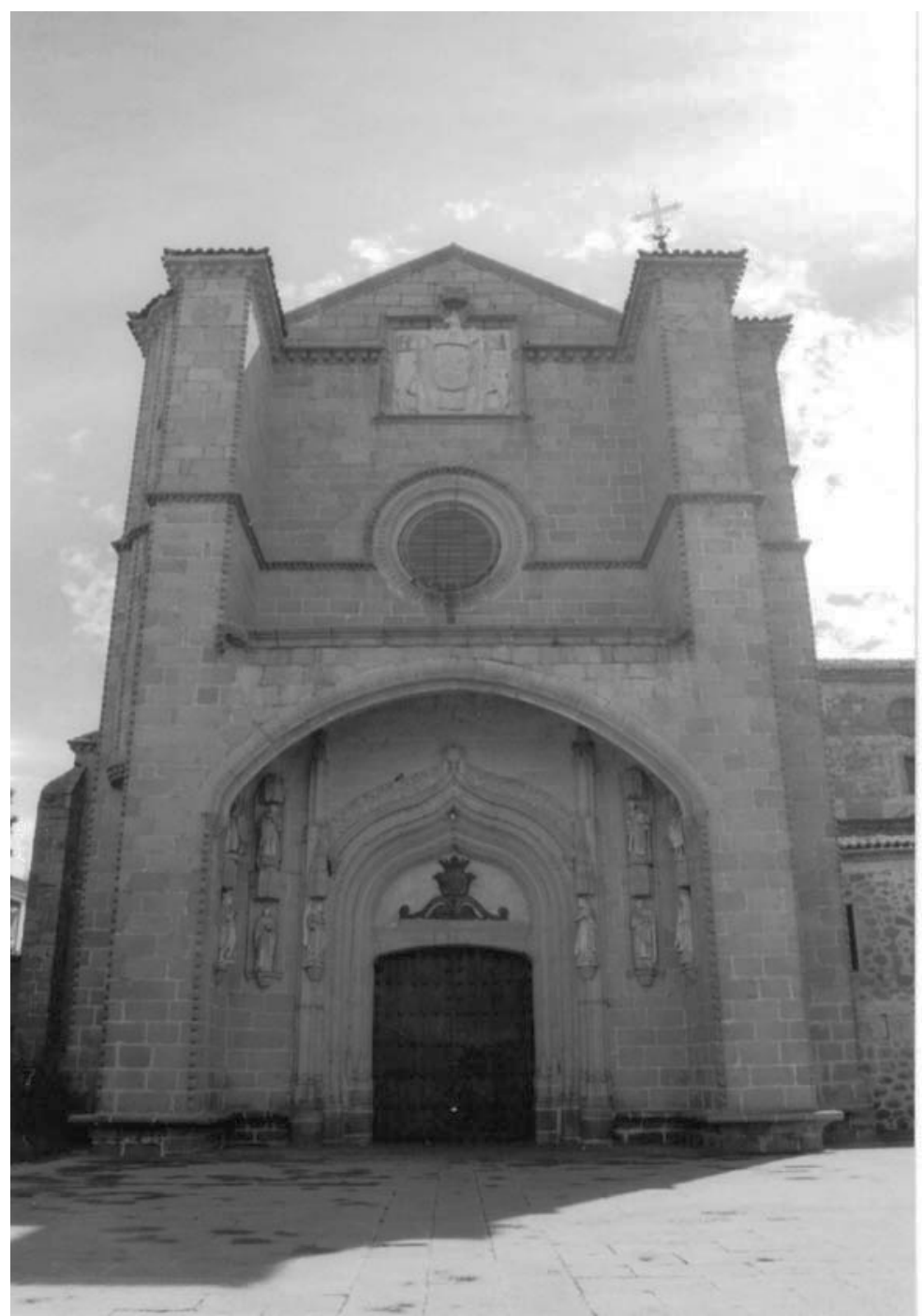

Fig. 1. Iglesia del Convento de Santo Tomás de Ávila 


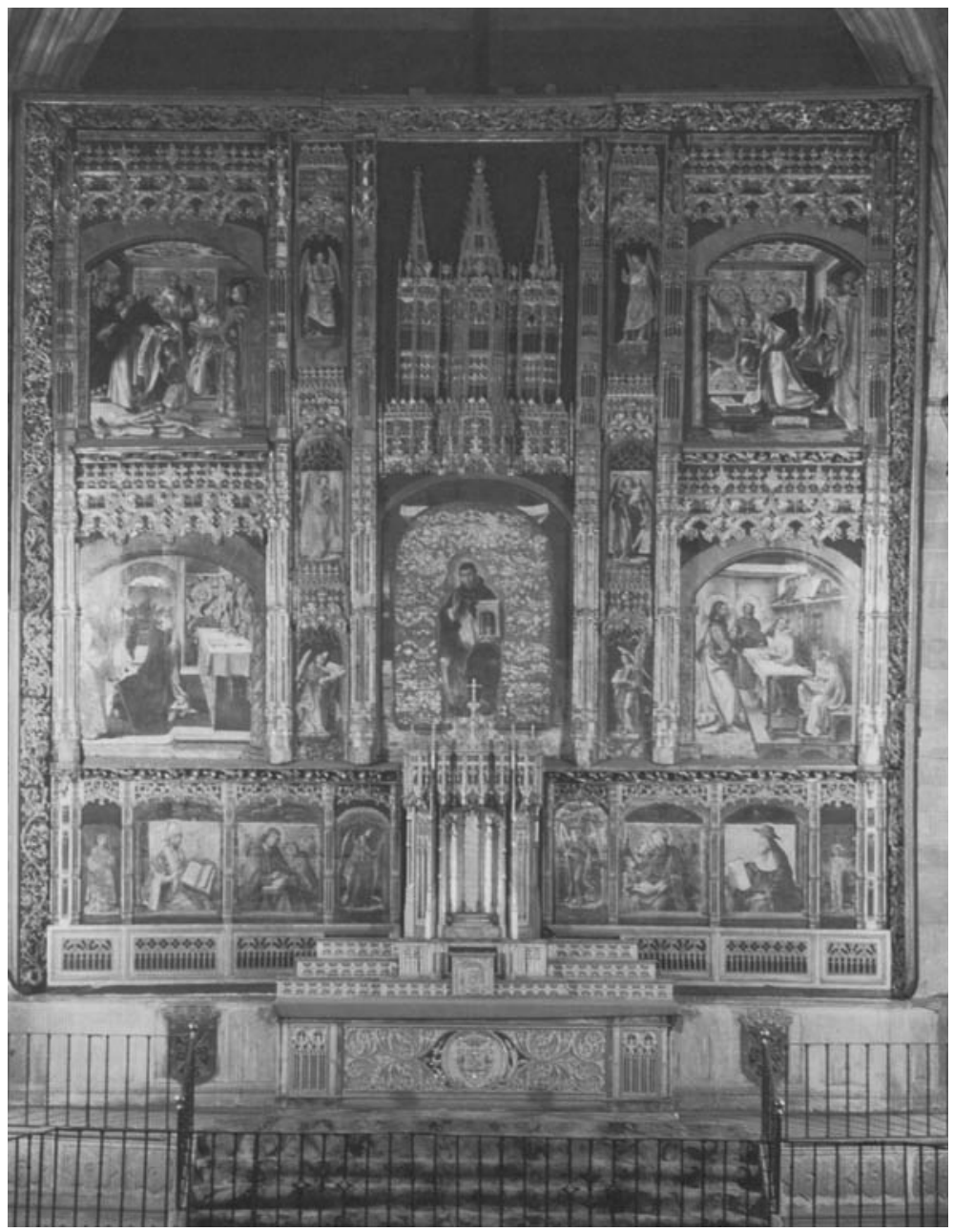

Fig. 2. Pedro Berruguete: Retablo Mayor. Iglesia del Convento de Santo Tomás de Ávila 


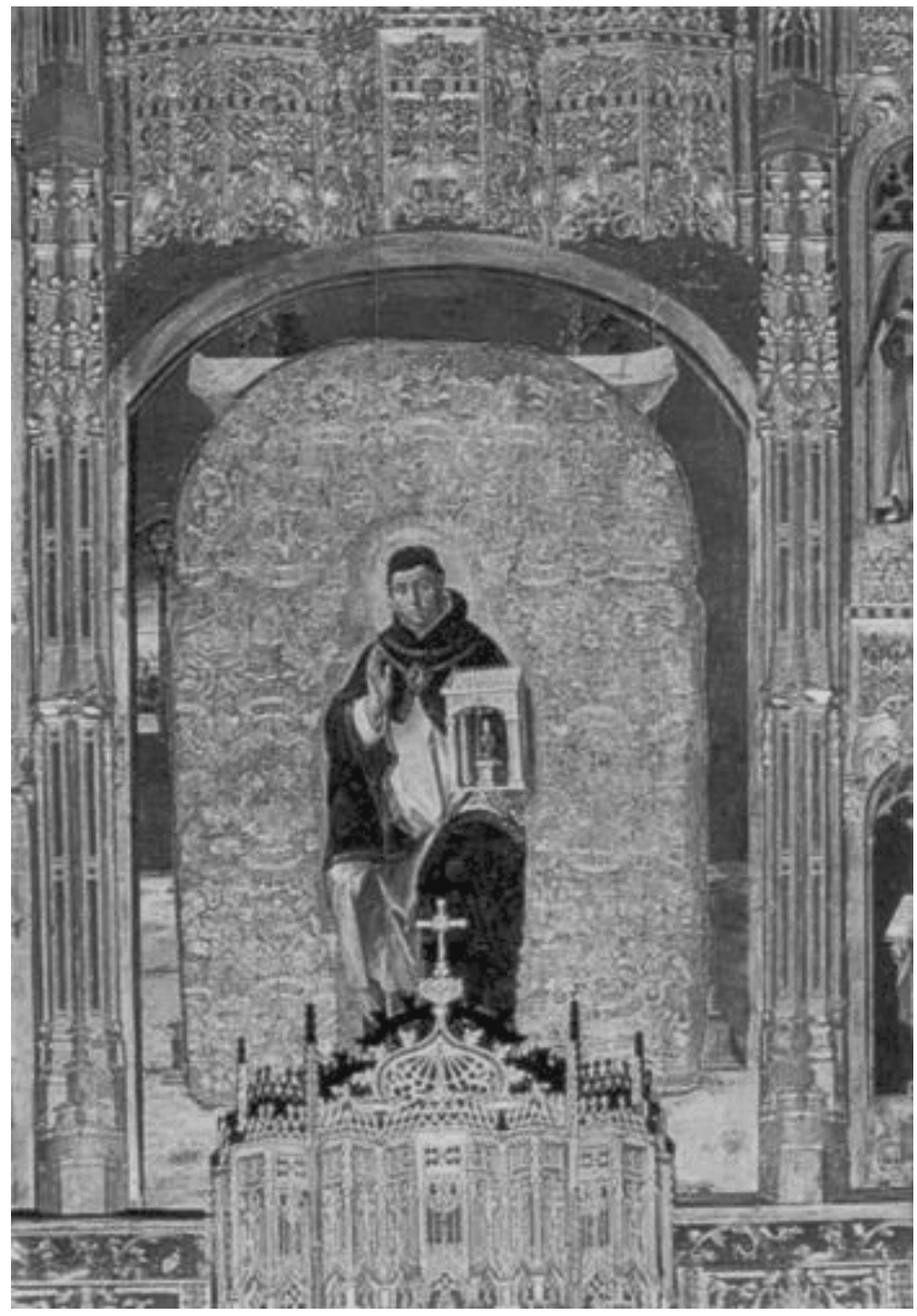

Fig. 3. Pedro Berruguete: Santo Tomás de Aquino, tabla principal del Retablo Mayor. Iglesia del Convento de Santo Tomás de Ávila. 


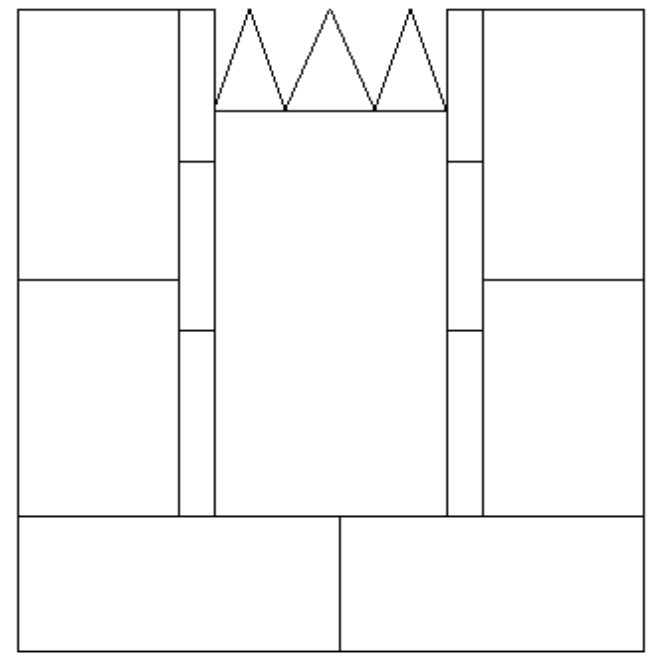

Fig. 4. Reconstrucción hipotética de los retablos de Santo Domingo de Guzmán y San Pedro de Verona. 


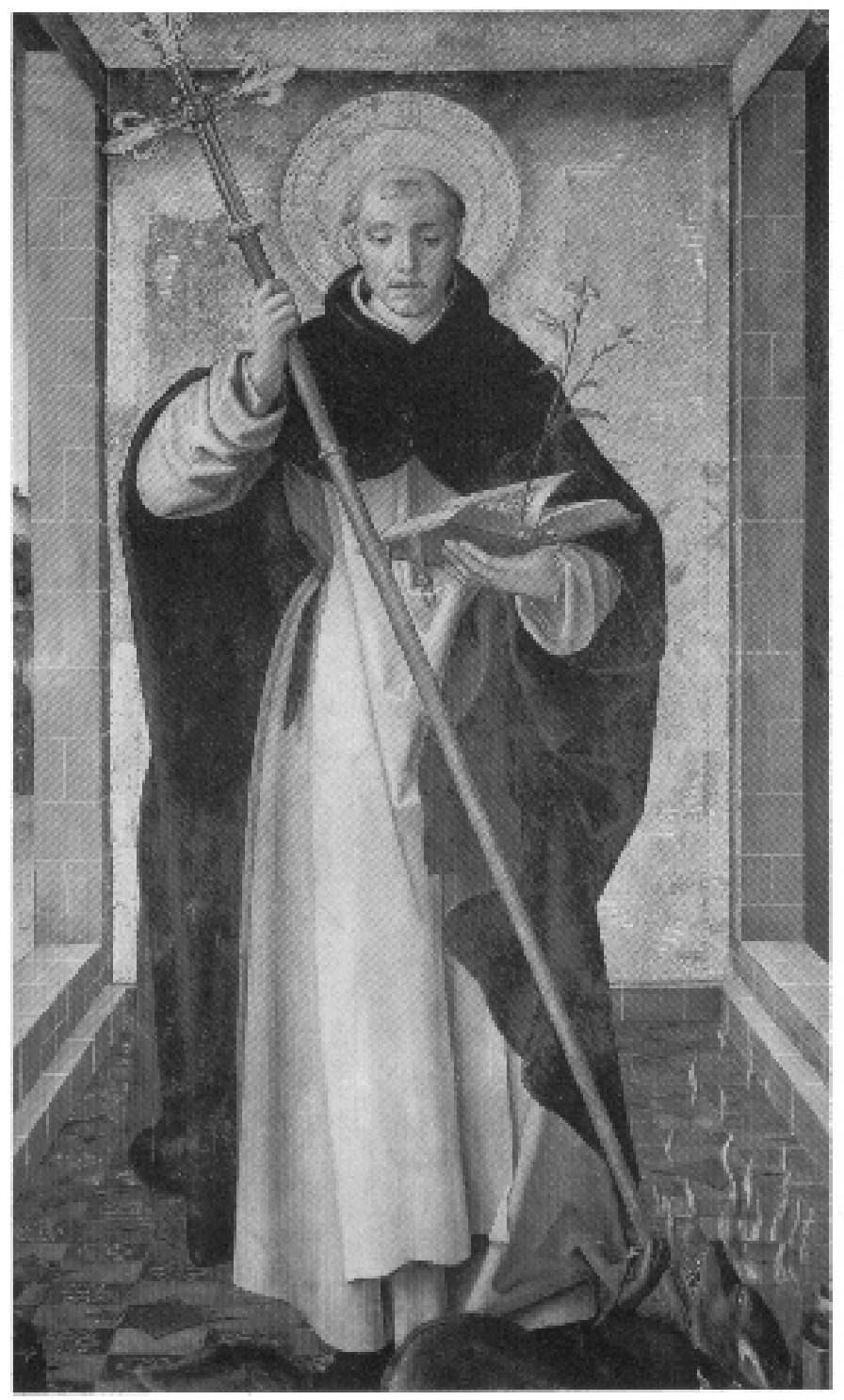

Fig. 5. Pedro Berruguete: Santo Domingo de Guzmán. Museo del Prado (Madrid). 


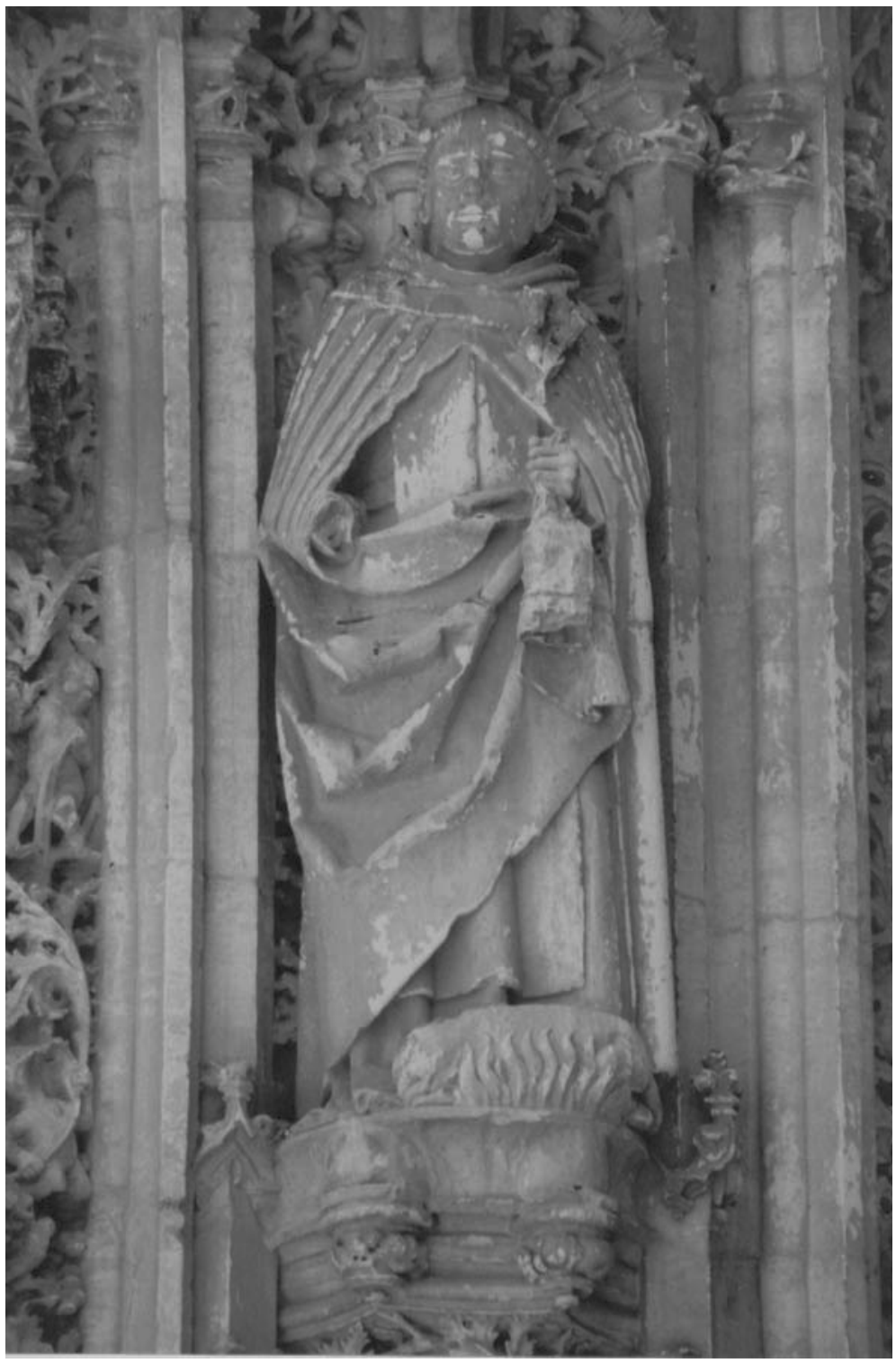

Fig. 6. Santo Domingo de Guzmán. Portada de la iglesia del Convento de Santa Cruz de Segovia. 


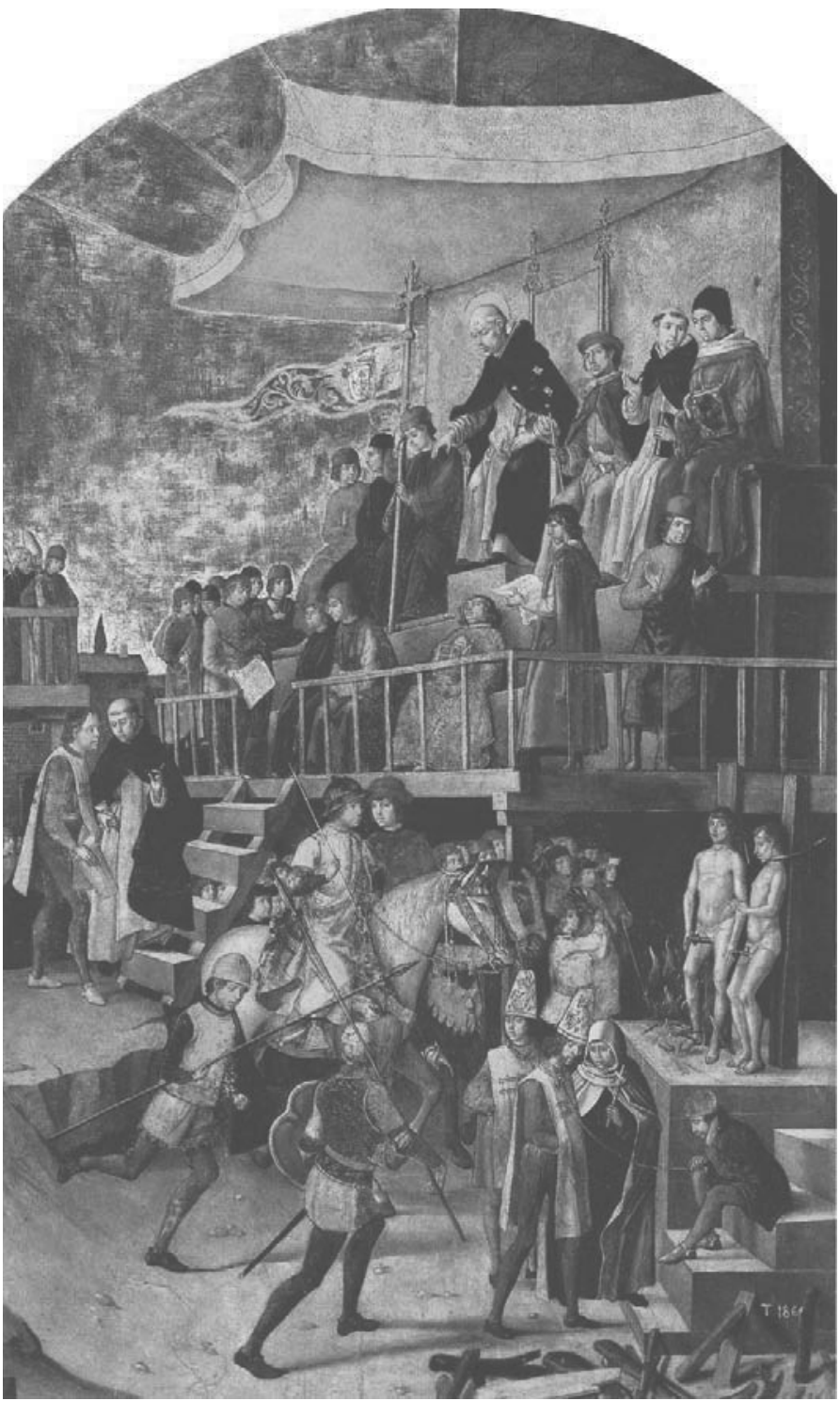

Fig. 7. Pedro Berruguete: Auto de Fe. Museo del Prado (Madrid) 


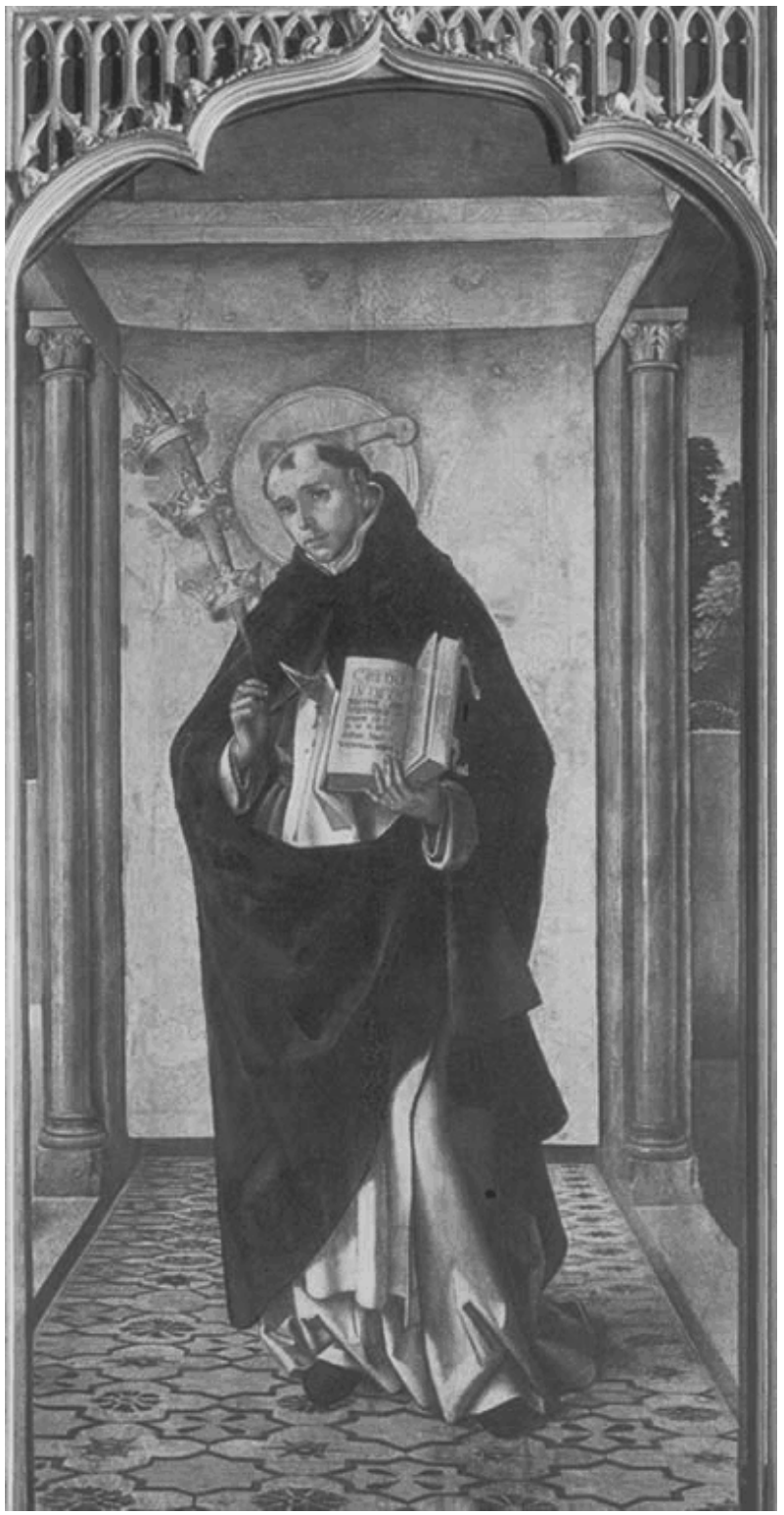

Fig. 8. Pedro Berruguete: San Pedro de Verona. Museo del Prado (Madrid) 